\title{
LETTING COMPANIES CHOOSE BETWEEN BOARD MODELS: AN EMPIRICAL ANALYSIS OF COUNTRY VARIATIONS
}

\author{
MARTIN GELTER* AND MATHIAS SIEMS**
}

\begin{abstract}
This article has a dual aim: it aims to contribute to the substance of comparative corporate law and it aims to advance the methodology of comparative legal research. In substantive terms, the article addresses the key question about the design of a suitable board structure. It notes that today many countries not only allow modifications of the default structure, but provide two separate legal templates by giving firms a choice between a one-tier and a two-tier board model. Yet, information on the actual choices made by companies is rare. This article aims to fill this gap. It presents original data about the choice of board models from fourteen European jurisdictions, analyzing variations of popularity of these models at the country level. For this purpose, the article applies the techniques of "correspondence analysis" and "qualitative comparative analysis," which have been developed by other academic disciplines but have so far been rarely employed in

\footnotetext{
* Fordham University School of Law, US.

${ }^{* *}$ European University Institute, Florence, Italy. We thank the participants of conferences, workshops and seminars at Católica Porto Business School, Columbia University, Hebrew University, National Taiwan University, The New School, Sichuan University, Vanderbilt University, and the Universities of Frankfurt, Hamburg, Leeds and Roma Tre for helpful comments. The authors thank Julia M. Puaschunder for introducing us to correspondence analysis, as well as for many conversations on this method, and Tomislav Jakšić, Anne Lafarre, Loes Lennarts, Ville Pönkä, Federico M. Mucciarelli, Gheorghe Buta, Radu N. Catană, David Oprea, and Remus Vaslan for extensive discussion about the Croatian, Dutch, Finnish, Italian, and Romanian data respectively. The remaining errors are entirely our responsibility.
} 
comparative legal scholarship. One of the main advantages of these techniques is that they do not depend on a large number of observations as is the case for econometric methods. They are also intuitive to use for legal scholars as they are not simply based on particular numerical scores (such as significant levels) but ask researchers to use their qualitative skills and knowledge in research design and evaluation. In conclusion, the new data and analyses show that there are profound country differences in the preferred choice for one of the board models and that both path dependence and legal differences can help to explain those variations.

Keywords: comparative corporate law, empirical comparative law, correspondence analysis, qualitative comparative analysis, path dependence 


\section{TABLE OF CONTENTS}

I. Introduction ................................................................... 140

II. Board Models and Availability of Choice in the EU ...142

a. One-tier, Two-tier, and Possible Further Models ....... 142

b. The Normative Discussion About Board Models........ 144

c. The Spread of Board Choice in the EU ........................146

III. The Popularity of Board Models Across Choice

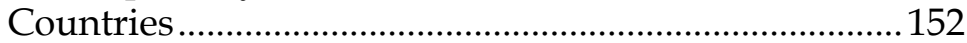

a. Limited Previous Research and Own Data Collection 152

b. Cross-Country Findings of this Study........................ 156

IV. What May Explain Country Variations in Preferred Board Models?.................................................................162

a. Possible Reasons for Different Preferences Across

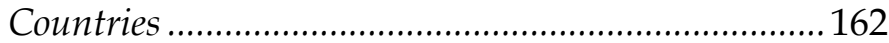

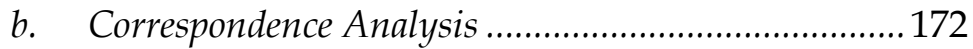

c. Fuzzy-set Qualitative Comparative Analysis ..............177

d. Idiosyncratic Factors ................................................ 181

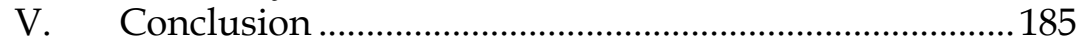




\section{INTRODUCTION}

Many private companies are simply managed by a single person. Yet, for public companies (joint-stock companies), having a suitable board structure is a key aspect of corporate governance. But how should such board structure be designed? From a comparative perspective, scholars often distinguish between a one-tier (or monist) model with a single board of directors and a two-tier (or dualist) model with a supervisory board and a management/executive board. ${ }^{1}$ Traditionally, the law of public companies only provides for one of these models, typically making it mandatory. However, there is also a trend to let companies freely choose their board model. This can be observed in most parts of the world: for example, a choice of board models for which the law provides two sets of templates is possible in countries as diverse as Algeria, Japan, Russia, Vietnam and, to some extent, also Brazil. ${ }^{2}$

In the European Union (EU), more than half of the Member States allow board choice in their laws of public companies today, and there is also such a rule for the special legal form of the European Company (SE) which can be chosen in all countries of the European Economic Area (EEA). ${ }^{3}$ How companies actually make use of this availability of board choice is, however, largely underexplored; 4 in particular there has not yet been an empirical exploration of all EU countries that allow such board choice today. The research project from which this article derives aims to fill this gap as it presents and analyses original data about the choice of board models from fourteen EU Member States (as well as the SE). This article in particular focuses on the variations of popularity of

For details see infra Part II.A.

2 Choice between one-tier and two-tier models in: Algeria (قانون التجارة [Code of Commerce] arts. 610, 642), Russia (Об акционерном обществе, [Federal Law of the Russian Federation on Joint Stock Companies] federal'nyı̌ zakon [Federal Law] 1995, No. 208-FZ, art. 64) (choice only for companies with less than fifty shareholders; larger companies need to be two-tier), and Vietnam (Luật Doanh nghiệp [Law on Enterprises], No. 59/2020/QH14, Art. 137) (Viet.) and between three models in Japan (会社法[Companies Act], Law No. 86 of 1995, 1995, arts. 32627), also with differentiations according to the size of the company). In Brazil, the choice between one-tier and audit model depends on the request of a ten percent minority of voting sharesholders or a five percent minority of nonvoting shareholders to appoint a board of auditors (Lei No. 6.404, de 15 de Dezembro de 1976, COL. LEIS REP. FED. BRASIL (t.1): de 15.12.1976, art. 161.

3 For details see infra Part II.C.

4 For details see infra Part III.A. 
particular models at the country level-and thus a topic of comparative corporate law - while companion articles will analyze the firm level data in detail. Doing so, this article also contributes to the more general comparative question how far both the design and the application of the same legal idea (here: enabling choice of board models) may be very different across countries, for example due to reasons of path dependence. ${ }^{5}$

A further innovation of this article is that it applies new formal techniques of empirical comparative law in order to understand different preferences in the use of the board models across countries. ${ }^{6}$ Given that the number of units is relatively small $(\mathrm{n}=14$, i.e., the fourteen EU Member States that allow board choice), it would not be feasible to use econometric tools which have been the main focus of discussions about the benefits and shortcomings of using methods of empirical legal studies in comparative law. ${ }^{7}$ By contrast, "correspondence analysis" and "qualitative comparative analysis" can be applied to this type of data. These techniques have so far been rarely employed in comparative legal scholarship. Thus, this article also aims to show that comparative law can benefit from such formal methods, not least since it is often concerned with comparisons between a small number of units. ${ }^{8}$

The structure of this article is as follows. Part II explains the different corporate board models and the availability of choice in more detail. Part III addresses the previous attempts of data collection and then presents its own empirical findings. Part IV

5 For this concept, see, for example, John Bell, Path Dependence and Legal Development, 87 TuL. L. Rev. 787, 809 (2013); Mark J. Roe, Path Dependence, Political Options, and Governance Systems, in COMPARATIVE CORPORATE GOVERNANCE: EsSAYS AND MATERIALs 165, 175-81 (Klaus J. Hopt \& Eddy Wymeersch eds., 1997).

6 For details see infra Part IV.

7 See, e.g., Holger Spamann, Empirical Comparative Law, 11 ANN. REV. L. Soc. SCI. 131(2015); Christoph Engel, Challenges in the Interdisciplinary Use of Comparative Law (Max Planck Institute for Research on Collective Goods, Discussion Paper No. 2020/29, 2020), https://ssrn.com/abstract=3739754 [https://perma.cc/N4D3$36 \mathrm{EU}]$.

8 This can also be seen in the main general books on comparative corporate law: for example, CARSTEN GERnER-BEuERLE \& Michael SCHILliG, COMPARATIVE COMPANY LAW (2019) (dealing with four countries); COMPARATIVE COMPANY LAW: A CASE-BAsed ApProach (Mathias Siems \& David Cabrelli eds., 2nd ed. 2018) (dealing with twelve countries); ANDREAS CAHN \& DAVID C. DONALD, Comparative COMPANY LAW (2nd ed. 2018) (dealing with three jurisdictions); MARCO Ventoruzzo et. AL., Comparative Corporate LaW (2015) (mainly dealing with nine countries). 
evaluates possible reasons for different preferences across the fourteen EU Member States. Part V concludes.

\section{BOARD MODELS AND AVAILABILITY OF CHOICE IN THE EU}

\section{a. One-tier, Two-tier, and Possible Further Models}

The historical starting point of corporate governance in most countries was the one-tier model, i.e., the model with a single board of directors. However, some early companies also had a two-tier structure: for example, it is said the Dutch East India Company (the VOC) already created a "sort of supervisory board" in 1623.9 In the subsequent centuries, the Netherlands also continued to have some companies with "supervisory directors" though this was not mandatory and the first codified provisions of the nineteenth century did not specify their rights and duties in any detail.10

As far as codified corporate law is concerned, it was the German law of the late nineteenth century that first deviated from the onetier model: first, a law reform from 1861 allowed the establishment of a supervisory board; second, as a substitute for reduced governmental oversight, the supervisory board was made mandatory in 1870; and, finally, a further reform from 1884 made membership of the management and the supervisory board incompatible. 11 Subsequently, this two-tier structure was adopted by law-makers elsewhere in Europe but also further afield, while other countries retained the original one-tier structure..$^{12}$

It may be argued that this stark divide is often blurred in practice. Today, many large public companies of either model have board committees of non-executive directors which comprise three of the core functions of the supervisory board (audit, remuneration,

9 Willem J.L. Calkoen, The One-Tier Board in the Changing and Converging World of Corporate Governance: A comparative study of boards in the UK, the US and the Netherlands 307 (Oct. 11, 2011) (Ph.D. thesis, Erasmus University Rotterdam), https://repub.eur.nl/pub/26502/ [https://perma.cc/K5G3-H7F3].

10 Id. at 307-21. For the current position in the Netherlands see infra Part II.C.

11 See Holger Fleischer, Der Einfluß der Societas Europaea auf die Dogmatik des deutschen Gesellschaftsrechts, 204 ARCHIV FÜR DIE CIVILISTISCHE PRAXIS 502, 523-24 (2004).

12 See, e.g., OECD, OECD CORPORATE GOVERnANCE FACTBOOK 174 (2021) [hereinafter OECD FACTBOOK], https://www.oecd.org/corporate/corporategovernance-factbook.htm [https:// perma.cc/B729-6HBJ]. 
appointment). ${ }^{13}$ Moreover, arguably the one-tier model allows arrangements that make it resemble the two-tier model. There are two ways of accomplishing this: (i) shareholders can elect only nonexecutive directors to the one-tier board, which leads to a clear split between the board and executives (in particular if executives regularly meet as a group) ${ }^{14}$; or (ii) the articles of association establish a separate group of "supervisors" charged with monitoring the conduct of the board. ${ }^{15}$ Yet, neither of these two arrangements would lead to a "true two-tier structure," as they would change the rules of codified corporate law that only empower the board of directors (not any groups of executives or supervisors created praeter legem). ${ }^{16}$

Some corporate laws also provide for explicit variants. For example, in some countries, companies have, or can have, a "board of (statutory) auditors" (e.g., Italy, Portugal, and Japan), which can be seen as vestigial version of the supervisory board as it is only entrusted to check the legality of management but not its business judgment. ${ }^{17}$ As with the supervisory board, the origins of this model go back to late nineteenth century when countries such as Italy and Japan considered adopting the still "softer" German rules on the supervisory board of the 1870 law but also blended those with the use of auditors in one-tier countries (e.g., under French and UK law).18

13 See, e.g., Paul L. Davies \& Klaus J. Hopt, Corporate Boards in EuropeAccountability and Convergence, 61 AM. J. COMPAR. L. 301, 334-35 (2013) (noting that these committees are often required by law, listing rules or recommended by corporate governance codes).

14 For example, in the United States, corporations are typically run by officers, and there is no requirement that they are members of the board. Today, in many corporations the only non-independent director is the CEO. Moreover, if there is no audit committee, the entire board is defined to be the audit committee, which means that all of its members must be independent. See Securities Exchange Act of 1934, 15 U.S.C. § 78(c)(a)(58)(B), amended by Sarbanes-Oxley Act of 2002, Pub. L. No. 107-204, § 205, 116 Stat 745, 773-74.

15 See, e.g., PETRI MÄNTYSAARI, COMPARATIVE CORPORATE GOVERnANCE: SHAREHOLDERS AS A RULE-MAKER 93 (2005) (stating that there is nothing in UK corporate law that would prevent companies from adopting a two-tier structure under their articles).

16 Introducing a two-tier structure may theoretically be possible in some onetier jurisdictions, but it would in practice likely be discouraged because of the absence of a domestic tradition or model.

17 See, e.g., OECD FАСТВOOK, supra note 12, at 139, 179.

18 See, e.g., Guido A. Ferrarini, Corporate Governance Changes in the 20th Century: A View from Italy, in CORPORATE GOVERNANCE IN CONTEXT: CORPORATIONS, STATES, 
The corporate laws of the Nordic countries are sometimes also characterized as hybrid models as they require a board of directors and an executive body (which sometimes can also be a single person). ${ }^{19}$ Yet, in contrast to the two-tier model (and the model with a board of auditors), it is possible to be a member of both of these bodies; thus, in our view, this Nordic model is better seen as a variant of the one-tier system ${ }^{20}$ since the latter model can also include a split between executives and non-executives. ${ }^{21}$

\section{b. The Normative Discussion About Board Models}

The main idea of the two-tier model is that a clear division of management and supervision leads to better control of management, in particular as it avoids the conflict of interests of

AND MARKETS IN EUROPE, JAPAN, AND THE US31, 34 (Klaus J. Hopt, Eddy Wymeersch, Hideki Kanda \& Harald Baum eds., 2005) (explaining the Italian's Commercial Code's rules on Companies); Hiroyuki Kansaku, The Role of Shareholders in Public Companies, in German AND Asian PerspeCtives on COMPANy LAW 243, 247 (Holger Fleischer, Hideki Kanda, Kon Sik Kim \& Peter Mülbert eds., 2016) (explaining the influence of German and American laws on Japanese corporate law); Bruce Aronson, Japanese corporate law and corporate governance in historical perspective, in RESEARCH HANDBOOK ON THE HISTORY OF CORPORATE AND COMPANY LAW 401, 409_ 10 (Harwell Wells ed., 2018) (discussing the "identity crisis" of the board of auditors given its ambiguous role); Haruhito Takada \& Masamichi Yamamoto, The "Roesler Model" Corporation, 45 J. JAPANESE L. 45, 56-57 (2018) (explaining the board of auditors provisions under the draft of the Japanese Commercial Code written by Hermann Roesler). Likewise, the Chinese supervisory board was inspired by the German model, but was given much smaller powers. See JIANGYU WANG, COMPANY LAW IN CHINA: REgUlation OF BUSINESS ORgANIZATIONS IN A SOCIALIST MARKET ECONOMY 189-91 (2014).

19 E.g., Wolf-Georg Ringe, German versus Nordic Board Models: Form, Function, and Convergence, 65 NORDIC J. BUSINESS 29 (2016) (providing a comparison between the Nordic and German approaches to the structure of corporate boards).

20 Klaus J. Hopt, Comparative Corporate Governance: The State of the Art and International Regulation, in COMPARATIVE CORPORATE GOVERNANCE: A FUNCTIONAL AND INTERNATIONAL ANALYSIs 3, 31 n.109 (Andreas M. Fleckner \& Klaus J. Hopt eds., 2013).

21 In fact, in many publicly traded firms in the United States today (especially the largest ones) the only non-independent director is the CEO. See SPENCER STUART, 2019 U.S. SPENCER STUART BOARD INDEX 1, 15 (2019), https://www.spencerstuart.com/-/media/2019/ssbi2019/us_board_index_2019.pdf [https://perma.cc/76XF-LU53] ("The CEO is the only non-independent director on $62 \%$ of S\&P 500 boards, an increase from $59 \%$ last year and $50 \%$ ten years ago."). 
executive board members in a one-tier model. ${ }^{22}$ Scholars have also argued that one-tier boards with both executive and non-executive directors have many practical problems: such boards face the risk of factional disputes, ${ }^{23}$ and executive board members may withhold information from the full board, which would result in brief and superficial board meetings. ${ }^{24}$ Finally, from a practical legislative perspective, the employee co-determination required by some European jurisdictions 25 can more easily be implemented in supervisory boards than in boards combining supervision and management. ${ }^{26}$

Supporters of the one-tier model present the reverse line of reasoning. They stress that it is helpful that, in the one-tier model, executive and non-executive directors can work together in the same board, in particular as this leads to a faster flow of information and, therefore, non-executive directors being better informed than members of the supervisory board. ${ }^{27}$ Having two boards can also create fractional disputes between these two boards, as it can lead to legal uncertainty resulting from the difficulty of distinguishing between monitoring and strategy setting. ${ }^{28}$ The supervisory board in particular may act too conservatively in rejecting good but risky projects. ${ }^{29}$ Finally, as a one-tier model is typically implemented with fewer persons than a two-tier model, it may also be less expensive for the company.

22 See, e.g., Brian ChefFins, COMPANy LAW: TheOry, Structure, AND OPERATION 623 (1997) (explaining the "clash of roles" problem within a unitary board structure); Caspar Rose, The New Corporate Vehicle Societas Europaea (SE): Consequences for European Corporate Governance, 15 CORP. GOVERNANCE: AN INT'L REV. 112, 115-16 (2007) (explaining organization of management in Societas Europaea).

23 Peter Böckli, Konvergenz: Annäherung des monistischen und des dualistischen Führungs- und Aufsichtssystems, in HANDBUCH CORPORATE GOVERNANCE 268 (Peter Hommelhoff, Klaus J. Hopt \& Axel v. Werder eds., 2009).

24 Manuel René Theisen \& Michael Hölzl, Corporate Governance, in DIE EuROPÄISCHE AKTIENGESELlschaft 310-11 (Manuel René Theisen and Martin Wenz eds., 2005).

25 See infra Part IV.A.

26 E.g., Klaus J. Hopt \& Patrick C. Leyens, The Structure of the Board of Directors: Boards and Governance Strategies in the US, the UK and Germany, in COMPARATIVE CORPORATE GOVERNANCE 116, 142 (Afra Afsharipour \& Martin Gelter eds., 2021) (employee co-determination call for a basic governance structure that, from the viewpoint of private parties, only a two tier-board model can provide).

27 See, e.g., Theisen \& Hölzl, supra note 24, at 310.

28 Böckli, supra note 23, at 267-68.

29 Ann B. Gillette, Thomas H. Noe \& Michael J. Rebello, Board Structures Around the World: an Experimental Investigation, 12 REV. FIN. 93 (2008). 
The two levels may also differ in the extent to which they permit shareholders to influence management. At least in the German version of the two-tier model, the supervisory board is responsible for appointing and removing members of the management, ${ }^{30}$ as well as making other key decisions, for instance about compensation. Depending on the firm's ownership structure and the relationship of the individuals involved, a two-tier model is therefore more likely to attenuate the direct influence of shareholders on management. ${ }^{31}$

Overall, it seems that there are good arguments for both models. It also leads us to the conclusion that (i) comparative empirical evaluations of different board models should be of interest to legal scholars and policymakers ${ }^{32}$ and (ii) that providing companies with the choice of board models may be a far-sighted strategy, as will be discussed in the following.

\section{c. The Spread of Board Choice in the EU}

Figure 1 displays the "original" and the current models of the board structures of public companies in Europe (with the precise law reforms shown in Table 1 below). While historically the vast majority of the countries only provided for (and allowed) a single board model, the law has gradually become more liberal in what is now a majority of Member States.

30 In other countries, shareholders may also have a say. See infra Part IV.A for the dismissal decision.

31 For this argument see also infra Part IV.A.

32 Most of the existing literature is focused on Anglo-American one-tier firms. See, e.g., Renée B. Adams, Benjamin E. Hermalin \& Michael S. Weisbach, The Role of Boards of Directors in Corporate Governance: A Conceptual Framework and Survey, 48 J. ECON. LITERATURE 58, 101 (2010). Empirical research of different board models has been rare. See Carsten Jungmann, The Effectiveness of Corporate Governance in OneTier and Two-Tier Board Systems - Evidence from the UK and Germany, 3 EUR. CO. \& FIN. L. REV. 426 (2006) (not finding a significant difference). For the limited research on the "choice countries," see infra Part III.A. 


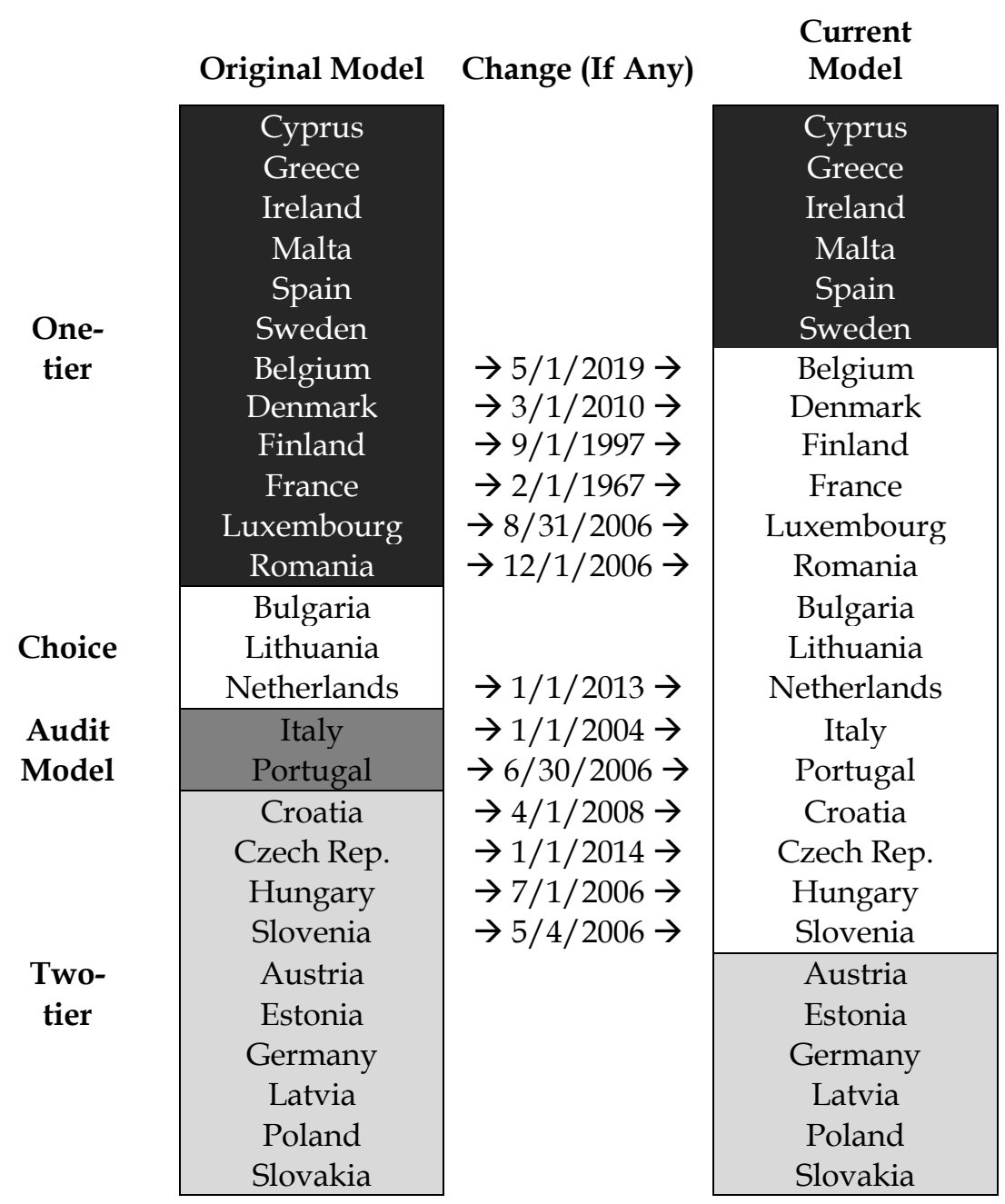

Figure 1: Overview of board structures of public companies 33

33 For the relevant laws of "choice countries," see infra Table 1. For one-tier

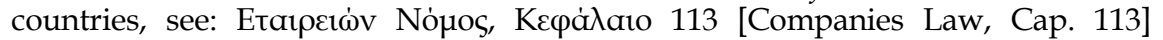

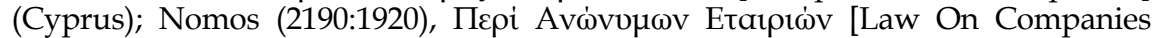
Limited by Shares] (Greece); Companies Act 2014 (Act No. 38/2014) (Ir.); Ta]t 1-Att dwar il-Kumpanniji [Companies Act] Cap. 386, 1995, https://meae.gov.mt/en/Public_Consultations/MJCL/Documents/Chapter\%20 386.pdf [https://perma.cc/MP9D-FPQ8] (Malta); Ley de Sociedades de Capital [Capital Companies Act] (B.O.E. 2010, 161) (Spain); AKTIEBOLAGSLAGEN (Svensk Författningssamling [SFS] 2005:551) (Swed.). For two-tier countries, see: AKTiEnGESETz [AKTG] [STOCK CORPORATION ACT] Bundesgesetz [BG] No. 31/1965, https://www.ris.bka.gv.at/Dokumente/BgblPdf/1965_98_0/1965_98_0.pdf [https://perma.cc/YJL2-8KXK] (Austria); Äriseadustik [Commercial Code] RIIGI 
The following clarifications need to be made: first, we have classified Denmark and Finland as original one-tier countries. Despite the somehow mixed nature of the Nordic model, as explained, it is best characterized as a variant of the one-tier model. ${ }^{34}$

Second, Bulgaria and Lithuania have been classified as "original" choice countries. This is due to the fact that the first versions of their post-communist corporate laws from the early 1990s already allowed choice of different board models. ${ }^{35}$ We did not consider any pre-communist corporate laws, as they are unlikely to be relevant for companies that exist today.

Third, the Netherlands can, with some hesitation, also be called a country with original choice. The main complication is that Dutch law provides different rules for different types of public companies. Smaller public companies were never restricted in their choice of board model. For larger public companies (to be precise, those companies that fall under the so-called "structure regime"), a reform from 1971 required a supervisory board. ${ }^{36}$ However, the reform of 2011 (in force since 2013) then again allowed choice of the one-tier model under certain restrictions for these large public companies (e.g., requiring non-executive directors), while also clarifying the use of a one-tier board with both executive and non-executive members for all companies.

$\begin{array}{llllll}\text { TEATAJA } & \text { [RT] } & \text { I } & 1995, & 26,\end{array}$ https://www.riigiteataja.ee/en/eli/ee/513072016002/consolide/current

[https://perma.cc/FJ8A-83Q9] (Est.); Aktiengesetz [AktG] [Stock Corporation Act], Sept. 6, 1965, BGBl I at 1089 (Ger.); Komerclikums [The Commercial Law], LATVIJAS VËSTNESIS 158/160 (Lat.); Kodeks spółek handlowych [KSH] [The Commercial Companies Code], Dz.U. tłum. gb Nr 94, poz. 1037 (Pol.); Obchodný zákonník (ObchZ) [Commercial Code], Act 513/1991 (Slovk.).

34 See supra Part II.A.

35 For the first post-communist corporate law in Bulgaria, see Cheryl W. Gray \& Peter Ianchkov, Bulgaria's Evolving Legal Framework for Private Sector Development 20-21, (WBG, No. WPS 906, 1992) https:/ / documents.worldbank.org/en/publication/documentsreports/documentdetail/630061468769498484/bulgarias-evolving-legalframework-for-private-sector-development [https://perma.cc/CJ9W-ERR2]. For Lithuania: Lietuvos Respublikos akcinių bendrovių įstatymas [The Republic of Lith. Joint Stock Company Law] (Aug. 1 1990), art 17, made the supervisory board optional for companies with fewer than fifty shareholders and 200 employees (similar to the Russian corporate law); LIETUVOS RESPUBLIKOS AKCINIŲ BENDROVIU̦ İSTATYMAS [The Republic of Lith. Joint Stock Company Law] ,art. 18(2) (July 20, 1994) later provided choice for all companies.

36 For a summary of the legal evolution since the 1970s, see GREGORY FrANCESCO MAASSEN, AN INTERNATIONAL COMPARISON OF CORPORATE GOVERNANCE ModELS 145-50 (1999). For the prior development, see Calkoen, supra note 9. 
Fourth, Hungary differentiates between two types of public companies: non-listed public companies (ZRT, zártkörüen müködő részvénytársaság) have complete choice, while for listed public companies (NYRT, nyilvánosan müködö részvénytársaság), the two-tier structure is the default option which can be replaced by the one-tier model under certain restrictions. Thus, overall, we regard Hungary as a choice country today, while prior to 2006 it was a two-tier country.

Fifth, Italy and Portugal initially had a system with a "board of auditors" (collegio sindacale in Italian; conselho fiscal or fiscal unico in Portuguese). However, with the respective reforms of the 2000s (see Table 1), the one and the two-tier models also became available. Thus, in these two countries, companies can now choose between three board models: the traditional model with a board of auditors, the two-tier model with a management and supervisory board, or the one-tier model with a single board of directors.

Table 1: Relevant laws of "choice countries" (as well as other countries)

\begin{tabular}{|l|l|l|}
\hline Country & Relevant Law Today & $\begin{array}{l}\text { Choice Enabled, with } \\
\text { Precise Law and Date It } \\
\text { Came into Force }\end{array}$ \\
\hline Belgium & $\begin{array}{l}\text { Code de } \\
\text { Commerce/Wetboek van } \\
\text { Koophandel [Code of } \\
\text { Commerce/Commercial } \\
\text { Code] } \\
\text { / Code des sociétés et } \\
\text { des associations } \\
\text { [Companies and } \\
\text { Associations Code] } \\
\text { 40586/2019. }\end{array}$ & $\begin{array}{l}\text { Law of March 23, 2019, } \\
\text { [elgisch Staatsblad [B.S.] } \\
\text { 2019/40586. In force since } \\
\text { May 1 2019 }\end{array}$ \\
\hline Bulgaria & $\begin{array}{l}\text { TъproBcKo npaBo } \\
\text { [Commercial Law] DV, } \\
48 / J u n .1991 .\end{array}$ & \\
\hline Croatia & $\begin{array}{l}\text { Zakon o trgovačkim } \\
\text { društvima [Company } \\
\text { Law] (as amended) }\end{array}$ & $\begin{array}{l}\text { Zakon o trgovačkim } \\
\text { društvima [Company Law] } \\
\text { Narodne novine [NN] [The } \\
\text { people's newspaper] } \\
\text { 107/2007. In force since } \\
\text { April 1, 2008 }\end{array}$ \\
\hline
\end{tabular}




\begin{tabular}{|c|c|c|}
\hline $\begin{array}{l}\text { Czech } \\
\text { Republic }\end{array}$ & $\begin{array}{l}\text { Zákon o obchodních } \\
\text { společnostech a } \\
\text { družstvech [Business } \\
\text { Corporations Act], Zákon } \\
\text { č. } 90 / 2012 \mathrm{Sb} \text {. }\end{array}$ & $\begin{array}{l}\text { Zákon o obchodních } \\
\text { společnostech a družstvech } \\
\text { [Business Corporations } \\
\text { Act], Zákon č. } 90 / 2012 \mathrm{Sb} \text {. }\end{array}$ \\
\hline Denmark & $\begin{array}{l}\text { Lov om aktie- og } \\
\text { anpartsselskaber } \\
\text { (Selskabsloven) [Act on } \\
\text { public and private } \\
\text { limited companies } \\
\text { (Companies Act)] }\end{array}$ & $\begin{array}{l}\text { Bekendtgoerelse nr. } 172 \text { af } \\
01.03 .2010 \text { om } \\
\text { selskabsloven. Amendment, } \\
\text { in force since March 1, } 2010\end{array}$ \\
\hline Finland & 624/2006 Osakeyhtiölain. & $\begin{array}{l}\text { 145/1997 Laki } \\
\text { osakeyhtiölain } \\
\text { muuttamisesta. In force } \\
\text { since September 1, } 1997\end{array}$ \\
\hline France & $\begin{array}{l}\text { CODE DE COMMERCE [C. } \\
\text { Com.] [Commerical } \\
\text { Code]. }\end{array}$ & $\begin{array}{l}\text { Loi 66-537 du } 24 \text { juillet } 1966 \\
\text { sur les sociétés } \\
\text { commerciales [Law 66-537 } \\
\text { of July 24, } 1966 \text { on } \\
\text { Commercial Companies], } \\
\text { JOURNAL OFFICIEL DE LA } \\
\text { RÉPUBLIQUE FRANÇAISE } \\
\text { [J.O.] [OFFICIAL GAZETTE OF } \\
\text { FRANCE] July 26, } 1966 \\
\text { rectificatif J.O. Oct. 19, } 1966 . \\
\text { In force since February 1, } \\
1967\end{array}$ \\
\hline Hungary & $\begin{array}{l}\text { Polgári Törvénykönyv } \\
\text { [PTK] [Civil Code] Book } \\
3 .\end{array}$ & $\begin{array}{l}\text { 1988. évi IV törvény a } \\
\text { gazdasági társaságokról } \\
\text { (Act VI of } 1988 \text { on Business } \\
\text { Associations) amended } \\
2006 \text { évi IV törvény a } \\
\text { gazdasági társaságokról } \\
\text { (Act VI of } 2006 \text { on Business } \\
\text { Associations). In force since } \\
\text { July 1, } 2006\end{array}$ \\
\hline Italy & $\begin{array}{l}\text { Codice Civile [C. c.] } \\
\text { [Civil Code]. }\end{array}$ & $\begin{array}{l}\text { Decreto legislativo } 17 \\
\text { gennaio } 2003, \text { n. } 6 \text {, in G.U. } \\
22 \text { gennaio 2003, n. 17. in } \\
\text { force since January 1, } 2004\end{array}$ \\
\hline
\end{tabular}




\begin{tabular}{|c|c|c|}
\hline Lithuania & $\begin{array}{l}\text { Lietuvos Respublikos } \\
\text { akcinių bendroviu } \\
\text { ịstatymas [Republic of } \\
\text { Lithuania Law on } \\
\text { Companies] no. VIII-1835 } \\
\text { (2000)Law of Companies } \\
2000 \text { (as amended). }\end{array}$ & $\mathrm{N} / \mathrm{A}$ \\
\hline Luxembourg & $\begin{array}{l}\text { Loi Concernat Les } \\
\text { Lociétés Commerciales } \\
\text { [Law on Commercial } \\
\text { Companies] (Règlement } \\
\text { Grand-Ducal] (Grand- } \\
\text { Ducal Regulation) Dec. 5, } \\
\text { 2017). }\end{array}$ & $\begin{array}{l}\text { Law of August 25, 2006, } \\
\text { Journal Officiel Grand- } \\
\text { Duché de Luxembourg } \\
\text { [Official Gazette of Grand- } \\
\text { Duchy of Luxembourg] } \\
\text { 821/2005. In force since } \\
\text { August 31, } 2006 \text {. }\end{array}$ \\
\hline Netherlands & $\begin{array}{l}\text { BURGERLIJK WETBOEK [C. } \\
\text { Code], } 2 \text { Boek [Book 2]. }\end{array}$ & $\begin{array}{l}\text { Besluit van } 6 \text { juni 2011, Stb. } \\
\text { 2011, 275. In force since } \\
\text { January 1, 2013, facilitated } \\
\text { the choice of the one-tier } \\
\text { model. }\end{array}$ \\
\hline Portugal & $\begin{array}{l}\text { CÓDIGO DAS SOCIEDADES } \\
\text { COMERCIAIS [Business } \\
\text { Associations Code]. }\end{array}$ & $\begin{array}{l}\text { Decreto-Lei no. 76-A/2006 } \\
\text { de } 29 \text { de Março } 2006 \\
\text { [Decree-Law no. 76- } \\
\text { A/2006], } \\
\text { https:/ /dre.pt/dre/detalhe } \\
\text { /decreto-lei/76-a-2006- } \\
\text { 620286 } \\
\text { [https:/ / perma.cc/94PW- } \\
\text { SZRD]. In force since June } \\
\text { 30, 2006. }\end{array}$ \\
\hline Romania & $\begin{array}{l}\text { Legii Societăților nr. 31 } \\
\text { [Companies Law no. 31] } \\
\text { Monitorul Oficial al } \\
\text { României [Official } \\
\text { Gazette of Rom.] no. } 583 \\
\text { (Nov. 1990). }\end{array}$ & $\begin{array}{l}\text { Ordinance } 441 / 2006 \\
\text { amending law } 31 / 1990 \text { on } \\
\text { Commercial Companies } \\
\text { published in the Official } \\
\text { Gazette no. 955/28.11.2006. } \\
\text { In force since December 1, } \\
2006 \text {. }\end{array}$ \\
\hline Slovenia & $\begin{array}{l}\text { Zakon O Gospodarskih } \\
\text { Družbah (ZGD-1) } \\
\text { [Companies Act], } \\
\text { URADNI LIST REPUBLIKE } \\
\text { SLOVENIJE [The Official } \\
\text { Gazette of the Republic } \\
\text { of Slovenia] 2006. }\end{array}$ & $\begin{array}{l}2006 \text { Act, in force since May } \\
4,2006 .\end{array}$ \\
\hline
\end{tabular}


Both Figure 1 and Table 1 show that the majority of countries introduced board choice since the mid 2000s. This is no coincidence since this reform was often done in conjunction with the implementation of the law of the European Company (SE, Societas Europaea). The SE Regulation, which came into force on October 8, 2004, explicitly allows SEs to have "either a supervisory organ and a management organ (two-tier system) or an administrative organ (one-tier system) depending on the form adopted in the statutes." 37 Thus, SEs from any country of the EEA (the EU Member States plus Iceland, Liechtenstein and Norway) can benefit from board choice. However, incorporation as an SE has strict requirements, such as a minimum share capital of EUR 120,000, and the need for two or more existing companies from different EEA countries (which would then merge, form a holding company, etc.). ${ }^{38}$ These may not be significant burdens for very large companies; however, this is different for the vast majority of public companies, in particular those that are not listed. ${ }^{39}$ Thus, less than $0.5 \%$ of the about 900,000 public companies established in the EU have the legal form of an SE; we will therefore only consider the SE at a supplementary level in this article.

\section{THE POPUlARITY OF BOARD MODELS ACROSS CHOICE COUNTRIES}

\section{a. Limited Previous Research and Own Data Collection}

The previous section has shown that there is both an extensive debate about the different board models and a growing number of countries that allow companies the choice of these models; yet, empirical data on the actual choices that companies make is rare.

37 Council Regulation (EC) No 2157/2001 of October 8, 2001 on the Statute for a European company (SE), art. 38(b).

38 Id. at art. 4(2) and art. 2(1)-(4).

39 For data on the proportion of listed and non-listed public companies, see infra Part III.B. 
Table 2: Dominant board models in previous studies

\begin{tabular}{|c|c|c|c|}
\hline Country & $\begin{array}{c}\text { LSE } \\
\mathbf{2 0 1 3}^{40}\end{array}$ & EFES 201941 & $\begin{array}{c}\text { Other } \\
\text { Studies }\end{array}$ \\
\hline Belgium & - & one-tier (са. 96\%) & \\
\hline Bulgaria & one-tier & two-tier (ca. 68\%) & one-tier 42 \\
\hline Croatia & two-tier & two-tier (ca. 100\%) & \\
\hline $\begin{array}{l}\text { Czech } \\
\text { Republic }\end{array}$ & - & two-tier (ca. 62\%) & \\
\hline Denmark & one-tier & two-tier (ca. 93\%) ) $^{43}$ & one-tier $^{44}$ \\
\hline Finland & one-tier & two-tier (ca. 93\%) & \\
\hline France & one-tier & one-tier (ca. 75\%) & one-tier ${ }^{46}$ \\
\hline Hungary & two-tier & two-tier (ca. 100\%) & \\
\hline Italy & one-tier & two-tier (ca. 98\%) $)^{47}$ & $\begin{array}{r}\text { board of } \\
\text { auditors } 48\end{array}$ \\
\hline Lithuania & one-tier & two-tier (ca. 75\%) & one-tier 49 \\
\hline Luxembourg & one-tier & one-tier (ca 65\%) & \\
\hline Netherlands & two-tier & two-tier (ca. 81\%) & $\begin{array}{r}75 \% \text { one-tier } \\
1995^{50}\end{array}$ \\
\hline Portugal & one-tier & one-tier (ca. $62 \%)^{51}$ & $\begin{array}{r}\text { board of } \\
\text { auditors } 52\end{array}$ \\
\hline Romania & two-tier & one-tier (ca. 87\%) & \\
\hline Slovenia & two-tier & two-tier (ca. 55\%) & \\
\hline $\begin{array}{l}\text { SE for all EEA } \\
\text { countries }\end{array}$ & & & two-tier53 \\
\hline
\end{tabular}

40 LSE ENTERPRISE, STUdY ON DiRECTORS' DUTIES AND LiABILITY 8 (2013), http:/ / eprints.lse.ac.uk/50438/1/_Libfile_repository_Content_GernerBeuerle\%2C\%20C_Study\%20on\%20directors \%E2\%80\%99\%20duties\%20and $\% 20$ lia bility\%28lsero\%29 [https:// perma.cc/345M-46MF].

41 Marc Mathieu, EFES, Annual Economic Survey of Employee Share OWNERSHIP IN EUROPEAN COUNTRIES 97 (2019), http:/ / www.efesonline.org/Annual\%20Economic\%20Survey/2019/Survey\%202 019.pdf [https:/ / perma.cc/NL3Q-DZWG] (based on 2,406 large listed companies).

42 Miroslav Mateev, Corporate Governance Problem and its Implications for Transition Economies, 5 CORP. OWNERSHIP \& CONTROL 335, 339 (2008) (sample from 2004 of large companies - for listed companies: nineteen one-tier and thirteen twotier; for unlisted companies: twenty-two one-tier and eleven two-tier).

43 It seems that this is meant to include the Nordic "hybrid model" (but see supra Part II.A and II.C).

44 Ringe, supra note 19, at 38 (only very few companies have adopted the twotier model). 
45 It seems that this is meant to include the Nordic "hybrid model" (but see supra Part II.A and II.C).

46 See François Belot, Edith Ginglinger, Myron B. Slovin \& Marie E. Sushka, Freedom of Choice Between Unitary and Two-Tier Boards: An Empirical Analysis, $112 \mathrm{~J}$. FIN. ECON. 364, 373 (2014) (SBF 250 companies-seventy-five percent one-tier); Benedicte Millet-Reyes \& Ronald Zhao, A Comparison Between One-Tier and Two-Tier Board Structures in France, 21 J. INT'L FIN. MGMT. \& ACCT. 279, 292 (2010) (data for 2004: 174 companies, sixty-six percent one-tier; for 1033 publicly traded companies: $91.7 \%$ one-tier). A further small-scale study of ninety-five French firms found that members of the supervisory board have less financial expertise than one-tier board members. See Thomas Jeanjean \& Hervé Stolowy, Determinants of Board Members' Financial Expertise - Empirical Evidence from France, 44 INT'L J. ACCT. 378 (2008).

47 In this study, it seems that the authors included firms using the board-ofauditors model in the data on two-tier companies.

48 See CAMERA Di COMMERCiO Milano MOnZA BrianZA LODI, SOCIETÀ E IMPRESA (2019), https://www.milomb.camcom.it/database-societario [https://perma.cc/5W2V-XX4E] (choose "Società e impresa 2019") (data on companies with alternative board models in Table 4); Carlo Bellavite Pellegrini \& Emiliano Sironi, Does a One-Tier Board Affect Firms' Performances? Evidences from Italian Unlisted Enterprises, 48 SMALL Bus. ECON. 213, 219 (2017) (data for 2013 with 46,280 companies: 168 one-tier, 113 two-tier, remainder board of auditors). See also Carlo Bellavite Pellegrini, Laura Pellegrini \& Emiliano Sironi, Alternative vs. Traditional Corporate Governance Systems in Italy: An Empirical Analysis, 8 PROBS. \& PERSP. IN MGMT. 4, 7 (2010) ("the total sample size is composed by 548 firms: $67.7 \%$ of companies adopted a traditional CGS, characterized by one board and an outside Audit Committee, and $32.3 \%$ of them implemented alternative ones"). For listed companies: CONSOB, REPORT ON CORPORATE GOVERNANCE OF ITALIAN LISTED COMPANIES 26 (2019) (data for 2018: 227 companies with audit model, two each for one-tier and two-tier model).

49 Data are only reported for listed companies: OECD, CORPORATE GOVERNANCE IN LITHUANIA 31 (2018), http://www.oecd.org/corporate/corporategovernance-in-lithuania-9789264302617-en.htm [https://perma.cc/UR38-7NAT] (19 out of 29 companies follow one-tier model). See Asta Aleliūnaitè \& Ceslovas Christauskas, Corporate Governance of Lithuanian Listed Companies, 306(73) FolIA Pomeranae Universitatis TechnOlOGiae Stetinensis 7, 22-26 (2013) (twenty-five out of forty-six companies follow one-tier model).

50 Maassen, supra note 36, at 146 (7,076 all companies; 1,824 two-tier; 7,453 onetier). See also INSTITUUT VOOR ONDERNEMINGSRECHT, EVALUATIE WET BESTUUR EN TOEZICHT (WETENSCHAPPELIJK ONDERZOEK, 2017), https://ncd.nl/wpcontent/uploads/2017/12/Evaluatie-Wet-Bestuur-en-Toezicht.pdf

[https://perma.cc/V6C3-D3HB] (data on board structure of Dutch companies, yet without identifying their legal form).

51 But this study includes no category for the board-of-auditors model.

52 CMVM, RELATÓRIO ANNUAL SOBRE O GOVERNO DAS SOCIEDADES COTADAS EM PORTUGAL 9 $(2014)$

http://www.cmvm.pt/pt/EstatisticasEstudosEPublicacoes/Publicacoes/governo sociedadescotadas/Documents/Relat\%C3\%B3rio\%20Governo\%20Sociedades $\% 20$ 2014.pdf [https://perma.cc/TLN7-K7AW] (for listed companies: thirty-one board of auditors; eleven one-tier; one two-tier). 
Table 2 lists some prior studies that have considered the choice of board systems. However, these studies have severe limitations as far as the identification of the dominant board model is concerned. The information in the LSE study is based on the mere opinions of local lawyers about the dominant model with no data collected, the EFES study only covers large listed companies and the remaining studies are also very limited in their coverage. It is therefore no surprise that these prior studies reach contradictory findings for a large number of countries (Bulgaria, Denmark, Finland, Italy, Lithuania, the Netherlands, Portugal, and Romania).

For the purposes of this project, we collected new data using the database Orbis (Bureau van Dijk). ${ }^{54}$ The main search was conducted on July 16, 2018 for the public companies of the fourteen Member States with board choice at this point in time (thus, excluding Belgium, which only allowed choice later on). ${ }^{55}$ In addition, we collected data on the board structures of the SEs in all thirty one EEA countries as of mid-2018 (thus, including the UK).

From Orbis, we downloaded available data for each public company of these fourteen countries, in particular information about "directors and managers." 56 Omitting companies that are inactive or dormant and removing companies with no meaningful information about board positions led to a total of 147,268 companies. Orbis does not code the board structure explicitly, but we developed an algorithm coded in $\mathrm{R}$ to determine the board structure based on the positions of active "directors and managers" as coded in Orbis. While the Orbis data are not always consistent across countries, they are consistent within countries. Thus, we had to determine the right approach to classify boards for each country

53 Anders CARlson, SE EUR. \& ETUI, SE COMPANIES 8-9 (2018), http:/ / www.worker-participation.eu/content/download/6230/103998/file/SEFactsFigures-2018-03-13\%20Bologna.pdf [https://perma.cc/62NP-MCDR]; Lars Hornuf, Abdulkadir Mohamed \& Armin Schwienbacher, The Economic Impact of Forming a European Company, 57 J. COMMON MKT. STUD. 659 (2019) (based on 118 observations); Felix Lamp, Value Creation and Value Destruction in the Societas Europaea: Evidence from the New Legal Form (Apr. 27, 2011) (thesis, Erasmus University Rotterdam), https://ssrn.com/abstract $=1728162$ [https://perma.cc/TLN7-K7AW] (based on forty-seven observations).

$54 \quad$ ORBIS, https://www.bvdinfo.com/en-us/ourproducts/data/international/orbis [https://perma.cc/A49L-XJ3Z].

55 For Hungary, we included both the ZRT and NYRT. See supra Part II.B. For France, we only included the SA, not the SAS which is functionally more equivalent to a private company.

56 Details of the procedure described in this paragraph are explained in a companion paper that analyses the firm level of this dataset in more detail. 
separately. Ultimately, for most countries it was feasible to treat all companies with individuals classified as a member of a supervisory board as two-tier companies, with all other companies classified as following the one-tier model. Yet, in some countries, terminologies were not clear (e.g., inconsistency in the use "board of directors" for either the one-tier board or the two-tier supervisory board) and it was also necessary to consider the choice of the audit model for Italy and Portugal, thus necessitating more complex sorting algorithms. We verified the accuracy of our algorithms by looking up publicly available information of sample companies online.

Orbis does not code the legal form of an "SE" as separate legal form in all EU countries. When conducting parallel searches for all EEA countries, merely searching for "SE" in the company name would lead to false positives. Thus, we employed the widely used ECDB database for $\mathrm{SEs}^{57}$ as a starting point as it explicitly states the board model of each SE. This database covered 3,017 companies (as of May 25, 2018) and it includes information about the board structure. However, as the ECDB database contains little further firm-level information, we matched these findings with Orbis data for these companies. This resulted in firm-level data for almost ninety percent of these SEs or 2,630 companies.

\section{b. Cross-Country Findings of this Study}

Using our own data, as outlined in the previous sub-section, Table 3 presents the general preference for one of the two-and for Italy and Portugal, one of the three-board models for the public companies of the fourteen countries of our study.

57 Eur. Co. Database, ETUI, http://ecdb.worker-participation.eu/ [https://perma.cc/J89T-NQMU]. 
Table 3: General data about public companies

\begin{tabular}{|l|r|r|r|r|r|}
\hline \multirow{2}{*}{ Country } & \multicolumn{2}{|c|}{$\begin{array}{c}\text { Number of Firms by } \\
\text { Board Structure }\end{array}$} & \multicolumn{2}{|c|}{ Further Information } \\
\cline { 2 - 6 } & $\begin{array}{c}\text { One- } \\
\text { tier }\end{array}$ & $\begin{array}{c}\text { Two- } \\
\text { tier }\end{array}$ & $\begin{array}{r}\text { Board of } \\
\text { Auditors }\end{array}$ & $\begin{array}{r}\text { Total } \\
\begin{array}{r}\text { Pumber of } \\
\text { Public } \\
\text { Companies }\end{array}\end{array}$ & $\begin{array}{r}\text { Percentage of } \\
\text { Listed } \\
\text { Companies }\end{array}$ \\
\hline Bulgaria & 8,539 & 57 & $\mathrm{n} / \mathrm{a}$ & 8,596 & $2.58 \%$ \\
\hline Croatia & 20 & 635 & $\mathrm{n} / \mathrm{a}$ & 655 & $22.75 \%$ \\
\hline Czech Rep. & 4,115 & 13,070 & $\mathrm{n} / \mathrm{a}$ & 17,185 & $0.08 \%$ \\
\hline Denmark & 35,316 & 31 & $\mathrm{n} / \mathrm{a}$ & 35,347 & $0.43 \%$ \\
\hline Finland & 239 & 7 & $\mathrm{n} / \mathrm{a}$ & 246 & $58.94 \%$ \\
\hline France & 14,962 & 93 & $\mathrm{n} / \mathrm{a}$ & 15,055 & $3.93 \%$ \\
\hline Hungary & 4,191 & 1,576 & $\mathrm{n} / \mathrm{a}$ & 5,767 & $0.66 \%$ \\
\hline Italy & 100 & 71 & 24,010 & 24,181 & $1.18 \%$ \\
\hline Lithuania & 265 & 15 & $\mathrm{n} / \mathrm{a}$ & 280 & $10.71 \%$ \\
\hline Luxembourg & 7,025 & 28 & $\mathrm{n} / \mathrm{a}$ & 7,053 & $0.95 \%$ \\
\hline Netherlands & 2,726 & 550 & $\mathrm{n} / \mathrm{a}$ & 3,276 & $4.79 \%$ \\
\hline Portugal & 24 & 4 & 22,367 & 22,395 & $0.23 \%$ \\
\hline Romania & 3,161 & 3,583 & $\mathrm{n} / \mathrm{a}$ & 6,744 & $5.10 \%$ \\
\hline Slovenia & 110 & 380 & $\mathrm{n} / \mathrm{a}$ & 490 & $7.14 \%$ \\
\hline
\end{tabular}

In addition to variations in the choice of board models, Table 3 shows that the total number of public companies varies considerably between jurisdictions. In some countries, we have data for fewer than 1,000 public companies (Croatia, Finland, Lithuania, Slovenia), while in others there are more than 10,000 (Czech Republic, Denmark, France, Italy, Portugal). These discrepancies are likely to reflect the size of the respective economies as well as different preferences of small and medium-sized businesses in the use of the form of a private or public company. ${ }^{58}$ They may also be due to the substance of the underlying legal rules: for example, in many countries, the rules for private and public companies differ in the fundamental question whether corporate law provides a set of default or mandatory rules. 59

58 For the fact that different types of firms are comprised in our data, see infra Part IV.A.

59 Eddy Wymeersch, Comparative Study of the Company Types in Selected EU States, 6 Eur. CO. \& FIN. L. REV. 71, 88-97 (2009). 
The exceptional Finnish situation with a low number of public companies is owed to the history of Finnish corporate law: here, separate forms for public and private companies were only introduced in 1997 and the rules for both forms are still largely identical60; however, due to requirements of EU law, minimum capital requirements are considerably higher for public companies. ${ }^{61}$ Thus, in Finland the only reason for choosing the form of a public company is to be able to get listed on a stock exchange. It is therefore not surprising that almost sixty percent of Finnish public companies are listed companies. By contrast, in most of the other countries of our study only few public companies are listed (see Table 3): thus, for the data analyzed in this study, it is worth keeping in mind that, while it concerns public companies, the vast majority of these companies $(98.5 \%)$ are privately held. 62

60 Manne Airaksinen \& Tom Berglund, Corporate Governance in Finland, in THE Nordic Corporate Governance Model 168-69 (Per Lekvall ed., 2014).

61 Id. (for the Finnish law requiring 80,000 EUR of minimum capital for public companies, as compared to 25,000 EUR for private companies). Note that EU law only requires minimum capital for public companies, as stated in Directive (EU) 2017/1132 of the European Parliament and of the Council of June 14, 2017 relating to certain aspects of company law, art. 45 (previously in the 2nd Company Law Directive). 2017 O.J. (L 169) 70.

62 See infra Part IV.A. 


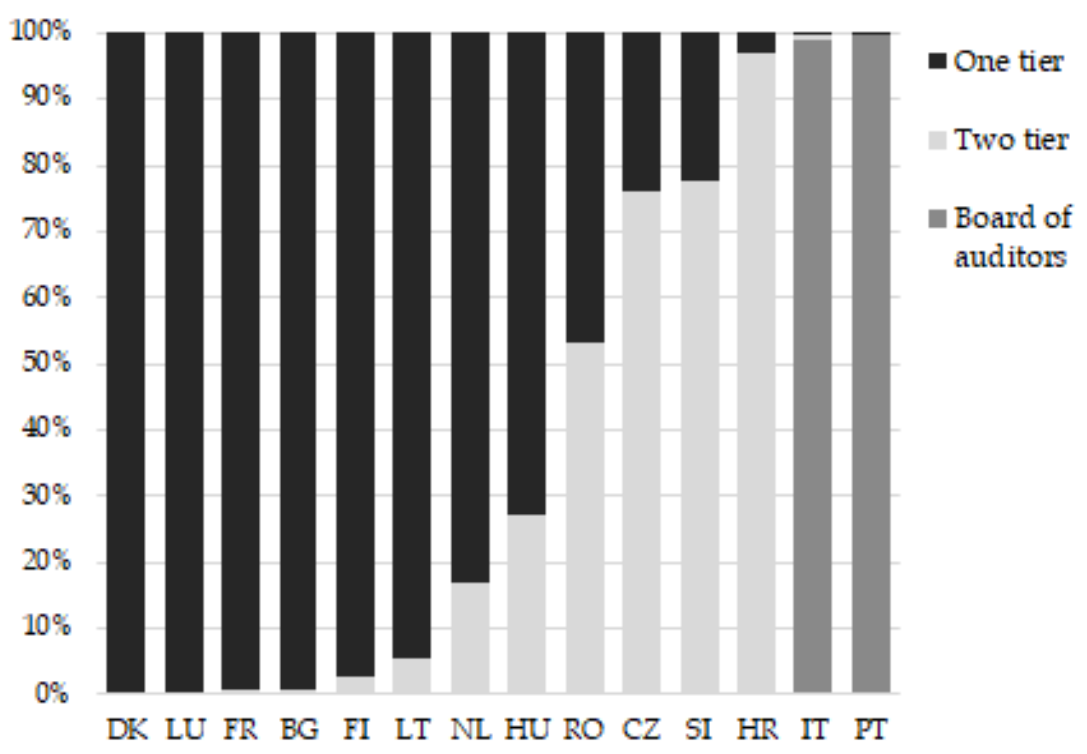

Figure 2: Choice of board models in public companies

For the purposes of comparing the "pure" choices, it is helpful to present the percentage of the total number of public companies for each of the countries: Figure 2 shows that, despite the availability of choice, some countries have a clearly dominant model: in Bulgaria, Denmark, France, Luxembourg and Portugal more than ninety-nine percent of the companies choose the same board model. There is somewhat more diversity in Croatia, Finland, Italy and Lithuania with one model that prevails with more than ninety-nine but less than ninety-nine percent. By contrast, the Czech Republic, Hungary, the Netherlands, ${ }^{63}$ Romania and Slovenia have a more balanced choice with no model used by more than ninety percent of the firms (and thus possibly a "true competition" between the different models).

In substance, it follows from Figure 2 that there is considerable diversity in choices between the one-tier or the two-tier model, while the board-of-auditors model has remained preeminent in Italy and

63 In the Netherlands, our data do not distinguish between "structure regime" (see supra Part II.C) or other companies. This means that smaller firms that have a unitary board without different categories of directors are classified as one-tier firms (as they are in other countries). 
Portugal. This result may be read as confirmation of the view that, perhaps, the one- and two-tier models operate similarly in practice and there is no clear benefit in choosing either of them.64 Yet, the analysis of the subsequent section will also identify that there are indeed several substantive reasons that account for choices of these models at the country level.

Comparing the number of countries with above fifty percent choice of either the one-tier or for the two-tier model, one-tier has an advantage of 8:4. This may reflect the preference of small and medium-sized businesses for the simpler one-tier structure. If we focus on the 2,280 companies ( $1.5 \%$ of our data, see also Table 3 ) that are listed, two-tier gains more support in almost all of the countries, with Hungary and the Netherlands now being predominantly twotier countries (with $76.3 \%$ and $70.1 \%$ ). ${ }^{65}$ The main anomaly is Romania, where the two-tier model is more popular for unlisted than for listed companies (55.1\% compared to 16.3\%). ${ }^{66}$

Considering the SE data for the same fourteen countries, we face the problem that only very few SEs have been established in most jurisdictions, with only four countries having more ten of them. Here, the general breakdown among the models is the same as in Figure 1: in the Czech Republic (the place where more than half of all SEs have been established ${ }^{67}$ ) two-tier leads with ninety-seven percent, while in the Netherlands, France and Luxembourg one-tier prevails with fifty-eight percent, seventy-six percent, and eighty percent. These latter figures are lower than the ones for domestic public companies (see Figure 1); thus, they may reflect the international nature of these SEs. Yet, these differences should also not be over-interpreted as they are only based on small numbers of companies (e.g., in France four two-tier SEs and thirteen one-tier SEs.

64 See supra Part II.A, II.B.

65 Also, note the different rules for large companies in both countries: see supra Part II C.

66 For a possible explanation, see infra Part IV.D.

67 For an analysis of this phenomenon, see Horst Eidenmüller \& Jan Lasák, The Czech Societas Europaea Puzzle, 12 J. CORP. L. STUD. 237, 237 (2012). 


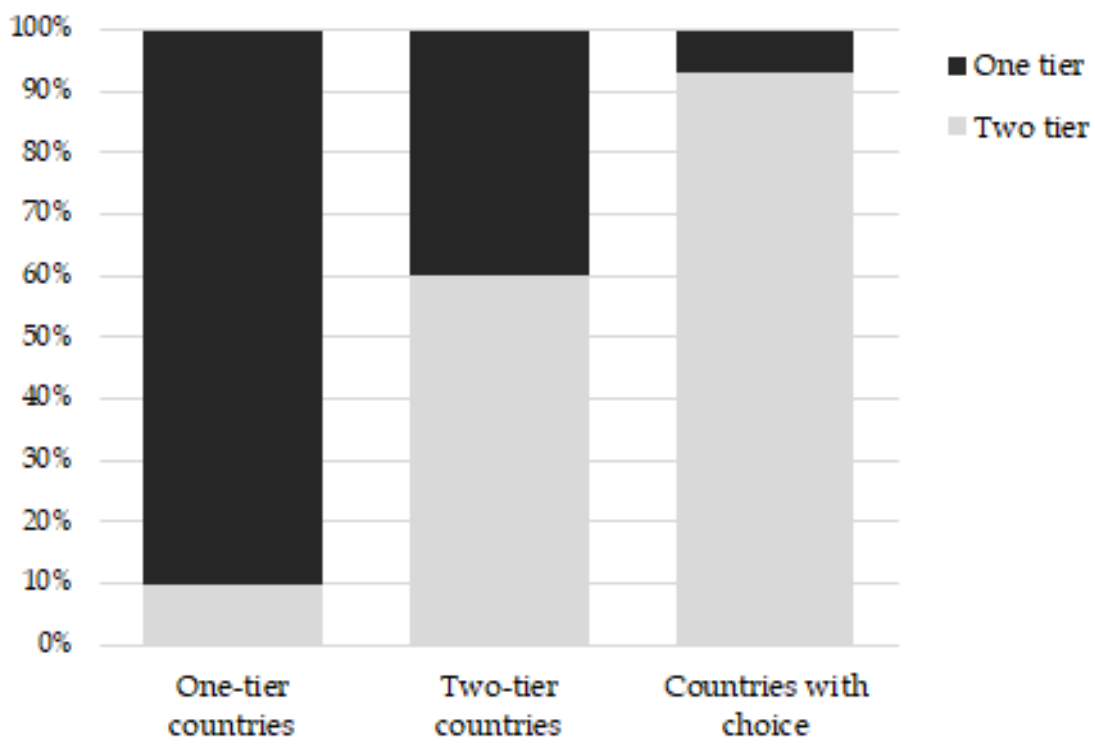

Figure 3: Board structures of SEs divided by domestic board models

The bar chart of Figure 3 displays the board choice of SEs for all thirty-one EEA countries, based on the classification of their current domestic board models. ${ }^{6} 8$ It shows that only ten percent of SEs from one-tier countries have chosen two-tier for the SE, while forty percent of SEs from two-tier countries apparently find the one-tier structure more attractive. 69 A possible interpretation is that for these latter companies the ability to choose the one-tier model has been one of the reasons why the legal form of the SE has been chosen in the first place, ${ }^{70}$ i.e., the data may reflect a desire of two-tier companies to switch to the one-tier model. ${ }^{1}$

68 See supra Part II.A.

69 The two-tier preference for the "choice countries" is entirely driven by the Czech Republic, as indicated in the preceding paragraph.

70 As also confirmed by Hornuf et al., supra note 53, at 669.

71 See infra Part IV.D. 


\section{WHAT MAY EXPLAIN COUNTRY VARIATIONS IN PREFERRED BOARD MODELS?}

\section{a. Possible Reasons for Different Preferences Across Countries}

This section explores reasons for variation in the preferred board model between the countries that allow the choice for domestic public companies (i.e., not merely the SE). Thus, the units of analysis are the fourteen countries (as displayed in Figure 2 above). Given this low number of observations, inferential statistics such as regression analysis would not be feasible. ${ }^{72}$ It would also be unrealistic to expect that other quantitative tools could provide determinative evidence of a causal relationship. Yet, this does not mean that it is impossible to explore reasons and develop hypotheses for differences between the fourteen countries. For this purpose, this section will use two other formal analytical methods, namely correspondence analysis and fuzzy-set qualitative comparative analysis (see IV.B and IV.C below), in order to gain some general insights. It then follows up with an exploration of idiosyncratic factors (see IV.D below).

Before doing so, this sub-section aims to identify possible reasons why a particular board model may be more popular in some countries than in others.

\footnotetext{
72 In regression models and more generally in statistical inference, a larger number of observations allows a researcher to make more precise estimates. A larger sample size will result in a smaller standard error, which allows a researcher to construct a narrower confidence interval and make it more likely to reject a null hypothesis. In other words, we are more likely to see statistically significant results with a larger sample size. On confidence intervals and hypothesis testing, see, for example, DAVID DIEZ, Mine ÇETINKAYA-RUNDEL \& CHRISTOPHER D. BARR, OPENINTRO STATISTICS 181-201 (4th ed. 2019).
} 


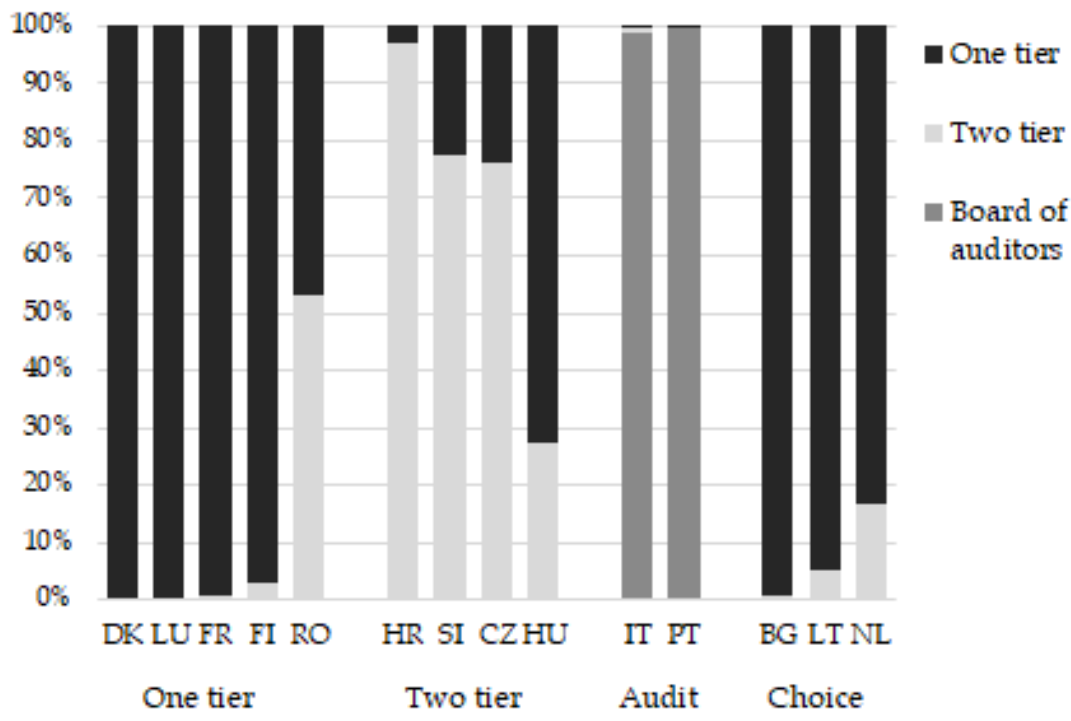

Figure 4: Choice of board models by traditional model

A first possible explanation for the differences between countries is that the traditional board model of a country, which now allows for choice today, may still reflect the preferences of the companies first established in that country. Thus, Figure 4 regroups the country differences (see Figure 2) according to the traditional models, ${ }^{73}$ which indeed seems to show that they continue to matter to some extent.

73 See supra Part III.B. 
[Vol. 43:1

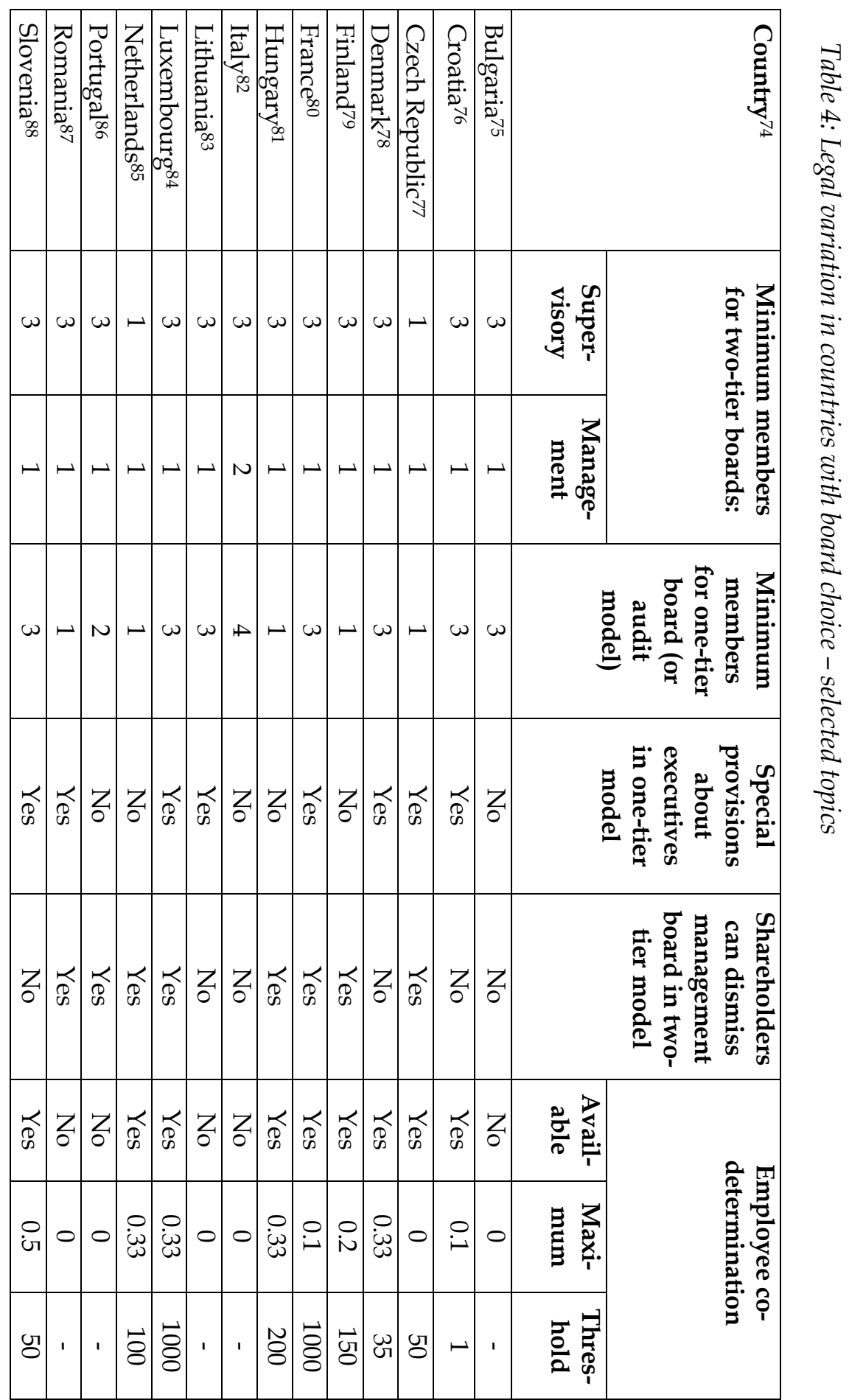


Secondly, legal variations may be a factor that explains differences in board choice. This does not mean that we need to consider all possible rules that address corporate boards. Since very few of the public companies in our dataset are listed $(1.5 \%$, see Table 3 and accompanying text above) rules that mainly or only apply to listed firms (e.g., about independent directors, board committees, gender diversity, executive remuneration, and compliance with

74 Footnotes 75-88 report the relevant provisions for the first five columns of Table 4. For the relevant laws, see supra Table 1. For the final three columns, which deal with employee co-determination, see Hornuf et al., supra note 53, and List of Countries under National Industrial Relations, WORKER-PARTICIPATION.EU, https://www.worker-participation.eu/National-Industrial-Relations/Countries [https:/ / perma.cc/298K-BVAC].

75 търговско право [Commercial Law] arts. 242(2), 241(4), 244, n/a, Arts. 221 and 233 (Bulg.).

76 Zakon o trgovačkim društvima [Company Law] arts. 254, 239, 272b, 272.1, 244 (Croat.).

77 Zákon o obchodních společnostech a družstvech [Business Corporations Act] 90/2012 Sb. Sec. 448(1), 439(1), 457, 463, 438(1) (Czech).

78 Lov om aktie- og anpartsselskaber (Selskabsloven) [Act on public and private limited companies (Companies Act)] (Mar. 2010), Art. 111 (Den.).

79 Osakeyhtiölaki [Companies Act] 6 Luku [Ch. 6] 624/2006, sec..23, 8, 8, n/a, 13 Companies Act (Fin.).

80 Code De Commerce [C. Com.] [Commerical Code] Arts. L225-69, L225-58 (at least for small companies), L225-17, L225-56, L 225-61 (Fr.).

81 Polgári Törvénykönyv [РТK] [Civil Code] arts. 3:26 and 3:121, 3:77 (but three for listed companies, art. 3:282), 3:77 (but five for listed companies, art. 3:282), n/a, 3:120 (Hung.).

82 Codice Civile [C. c.] [Civil Code] arts. 2409-duodecies, 2409-nonies, 2397 (and 2409-octiesdecies: one director and three committee members), n/a, 2409terdecies (It.).

83 Company Law 1994 supra, note 35, arts. 31(2), 33(2), 33, 37, 33(10) (Lith.).

84 Loi Concernat Les Lociétés Commerciales [Law on Commercial Companies] (Règlement Grand-Ducal] (Grand-Ducal Regulation) Dec. 5, 2017) arts. 442-14, 4412, 441-2, 441-11, 442-5 (Lux.).

85 BurgerlijK Wetboek [C. Code], arts. 2:140, n/a, n/a, n/a, 2:147 (dismissal by general meeting possible if provided in the articles) (Neth.); see also the special rules for companies that need to follow the "structure regime" (cf. supra Part II.C), for example, on the number of supervisory board members and their appointment and dismissal: arts. 2:158, 2:162.

86 Código Das Sociedades Comerciais [Business Associations Code], arts. 413(4), 424, 390 (one director and single auditor), n/a, 430 (Port.).

87 Legii Societăților nr. 31 [Companies Law no. 31] Monitorul Oficial al României [Official Gazette of Rom.] no. 583 (Nov. 1990) arts. 153.6, 153 (but three if audited), 137 (but three if audited), 143, 153.2.

88 Zakon O Gospodarskih Družbah (ZGD-1) [Companies Act], URADNI LIST RePUbliKe SLOVENIJE [The Official Gazette of the Republic of Slovenia] 2006, arts. $254,265,290,268$ 
corporate governance codes) are unlikely to be a relevant factor in our case. Moreover, because this section explores the reasons for the degree of popularity of board models in a given country, rules which are ty pically identical or similar for different board structures within the same country (e.g., the definition and enforcement of directors' duties) are also not relevant here.

Table 4 outlines some of the core differences in corporate law and employee co-determination that could potentially be relevant. 89 The first three columns are based on the possibility that needing to find and pay more members for the board (or boards) may be seen as a burden. By contrast, we did not consider provisions on the maximum number of board members as they are likely to be relevant for only the small number of very large companies and thus not general preferences at the country level.

The subsequent two variables consider that the design of board model may dilute the "pure" versions of the one-tier and two-tier model. ${ }^{90}$ Thus, the next column is about special provisions addressing the role of executives in the one-tier model, for example, specifying the applicable appointment procedure, the duration of appointment and their scope of responsibilities. Potentially, this can weaken the appeal of just having a single board as it imposes legal rules for two groups of persons (board members and executives), akin to the two-tier model. ${ }^{91}$ In some jurisdictions using the two-tier model the supervisory board may be rather weak (and, thus in some respects, rather like the hybrid board-of-auditors model). Specifically, the two-tier model may be more burdensome than the one-tier model if it means that shareholders cannot appoint or dismiss the members of the management board. In companies with large shareholders, it can also be relevant as the two-tier model can then serve their entrenched interests vis-à-vis changing positions in

89 For discussion of additional legal variations, see, for example, Hanjo Hamann, Unpacking the Board A Comparative and Empirical Perspective on Groups in Corporate Decision-Making, 11 BerKeley Bus. L.J. 1 (2014); Eur. Parl. Doc. (PE 462.454),

https://www.europarl.europa.eu/RegData/etudes/etudes/join/2012/462454/IP OL-JURI_ET(2012)462454_EN.pdf [https://perma.cc/WB3H-GNUA] (study by the European Parliament's Committee on Legal Affairs on "Relations between company supervisory bodies and the management'); OECD FАСТВOOK, supra note 12 , at $139-242$.

90 For the general difference between board models, see supra Part II.A.

91 This topic was discussed in Germany in detail when the government introduced the one-tier model for the SE. See, e.g., ANSGAR SCHÖNBORN, DIE Monistische SOCIETAS EuROPAEA IN DEUTSCHLAND IM Vergleich ZUM ENGLISCHEN RECHT (2007). 
the shareholder meeting. While the two-tier model historically left this question to the articles of association, a reform of German law from 1937 mandated that only the supervisory board had the power to appoint and dismiss members of the management board. 92 Countries following this model are coded as "no" in the above table, whereas jurisdictions where shareholders can always remove management board members, or where it depends on the articles, are coded as "yes." 93

Finally, the last three columns of Table 4 reflect that it could be relevant that employee co-determination can more easily be implemented in supervisory boards than in boards which combine supervision and management. ${ }^{94}$ Thus, these columns report the general availability of co-determination, their maximum level in terms of required employee board-members and the threshold of the number of employees triggering the applications of these rules.

92 Aktiengesetz [AktG] [Stock Corporation Act], Jan. 30, 1937, RGBl. I at 120, $\S 75(1)$ (Ger.). On the political context and the goal of reducing the influence of shareholders, see Thilo Kuntz, German Corporate Law in the 20th Century, in RESEARCH HANDBOOK ON THE HISTORY OF CORPORATE AND COMPANY LAW 205, 216-19 (Harwell Wells ed., 2018).

93 It depends on the articles in the Czech Republic, Finland, Hungary, and the Netherlands. See supra Table 1. Other topics related to the dismissal of directors (e.g., whether cause is needed) are typically the same for different board models within each country.

94 See supra Part II.B. 
Table 5: Firm-level variations for public companies - selected mean data

\begin{tabular}{|l|r|r|r|r|r|}
\hline Country & $\begin{array}{l}\text { Number of } \\
\text { Directors }\end{array}$ & $\begin{array}{l}\text { Number of } \\
\text { Employees }\end{array}$ & $\begin{array}{c}\text { Number of } \\
\text { Shareholder } \\
\mathbf{s}^{96}\end{array}$ & $\begin{array}{c}\text { Largest } \\
\text { Share- } \\
\text { holder } \\
\text { (in \%) }\end{array}$ & $\begin{array}{c}\text { Total } \\
\text { Assets (in } \\
\text { Thousand } \\
\text { sof USD) }\end{array}$ \\
\hline Bulgaria & 3.37 & 82.02 & 2.68 & 75.12 & 17,645 \\
\hline Croatia & 6.84 & 318.59 & 4.39 & 62.34 & 76,033 \\
\hline Czech Rep. & 2.43 & 96.29 & 0.49 & 97.41 & 38,323 \\
\hline Denmark & 4.81 & 83.29 & 1.79 & 79.33 & 54,212 \\
\hline Finland & 26.59 & $2,287.77$ & 24.78 & 42.60 & $2,246,458$ \\
\hline France & 9.42 & 496.51 & 2.53 & 70.35 & 251,048 \\
\hline Hungary & 6.18 & 127.87 & 1.24 & 86.07 & 59,328 \\
\hline Italy & 9.36 & 243.42 & 9.17 & 66.48 & 140,059 \\
\hline Lithuania & 4.29 & 293.00 & 2.22 & 69.87 & 236,995 \\
\hline Luxembourg & 3.82 & 283.64 & 1.84 & 78.49 & 181,830 \\
\hline Netherlands & 5.37 & $1,636.68$ & 2.11 & 86.70 & 466,732 \\
\hline Portugal & 5.21 & 82.14 & 1.67 & 72.54 & 44,161 \\
\hline Romania & 5.54 & 114.42 & 3.83 & 74.80 & 18,854 \\
\hline Slovenia & 6.11 & 331.66 & 3.56 & 63.18 & 189,027 \\
\hline Total & 5.83 & 182.74 & 3.10 & 75.69 & 102,215 \\
\hline
\end{tabular}

Thirdly, additional reasons for variations in preferences may be due to the fact that different types of firms are incorporated as public companies in the fourteen countries. Table 5 reports some of the descriptive statistics of the firm-level data. ${ }^{97}$ For example, it could matter that categories such as the number of directors, employees and shareholders, the prevalence of large shareholders and the total assets of the company may have an impact on board choice. ${ }^{98}$ These categories are also correlated with each other: for example, we already noted that in Finland, but not in the other countries, many of the public companies are listed companies. Thus, it is also plausible that, according to Table 5, Finnish companies have the

95 As reported in Orbis, supra note 54 (namely in its category "number of current directors \& managers," which also includes some top-level executives).

96 This column only includes information about known shareholders. In particular, in the Czech Republic, there seems to be either missing data in Orbis or a large number of shelf companies.

97 As collected from Orbis, see supra Part III.A.

98 This will also be analyzed in a firm-level focused companion paper. 
largest numbers of directors, employees and shareholders, the lowest ownership concentration, and the highest total assets. ${ }^{99}$

99 In addition, this information would be correlated with the preference of SMEs for one of the two types of companies (a private company or a public company). For this topic, see also Wymeersch, supra note 59. 


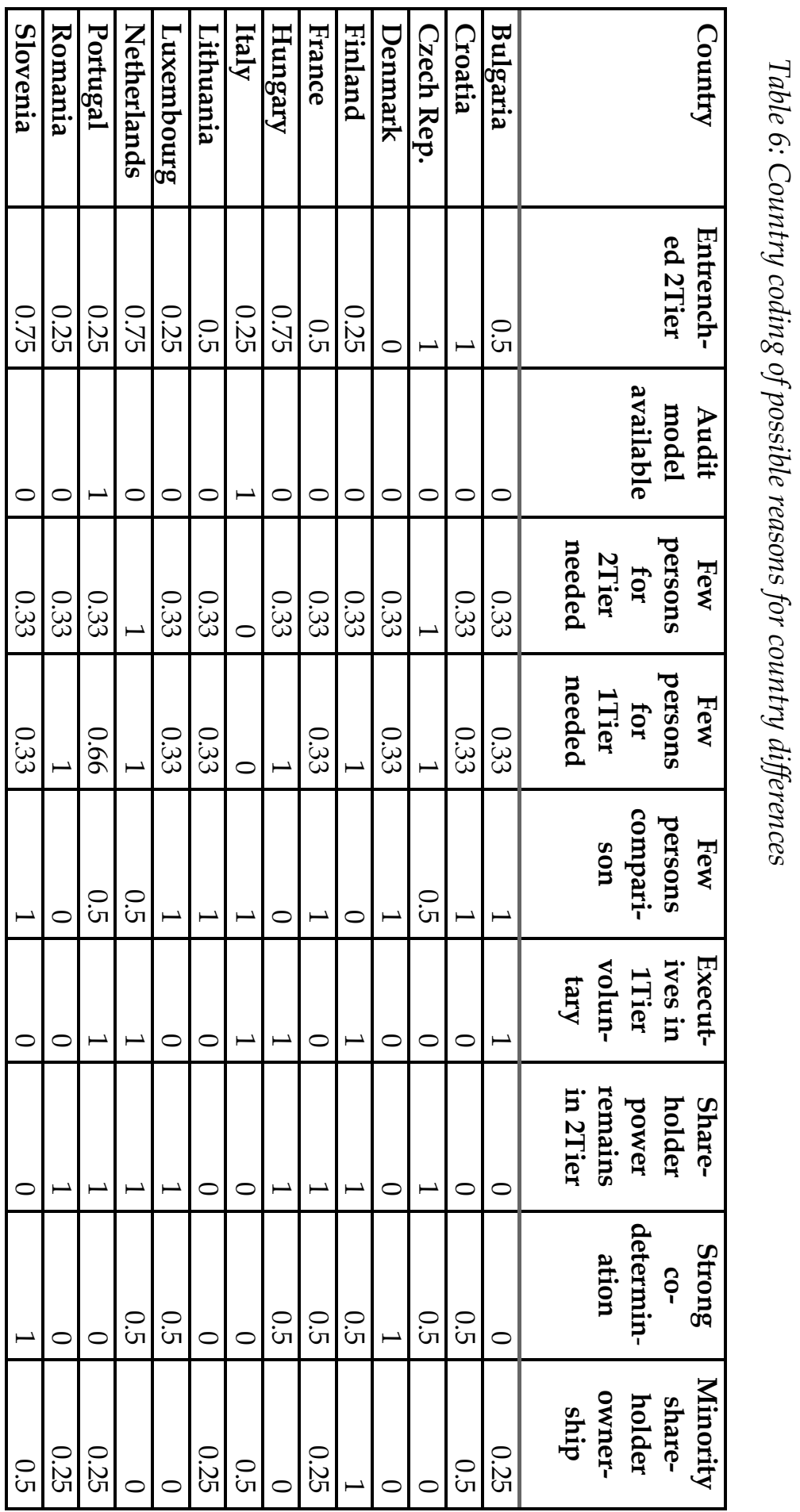


For the purposes of the subsequent analysis, we had to code the relevant variables of Tables 3 and 4 at a scale from 0 to 1, as displayed in Table 6. In particular, this was necessary for the subsequent use of the fuzzy-set qualitiative comparative analysis method as it requires the researcher to specify "membership scores" indicating whether units belong, or partly belong, to these categories. 100 Table 6 therefore codes the following information: (i) the variable on "entrenched two-tier" considers the traditional board model of the country and length of time choice has been available101; (ii) a binary variable codes for Italy and Portugal the availability of a "third model"; (iii) three variables code the number of persons needed for the two models 102 ; and (iv) two binary variables reflect the abovementioned rules on "special provisions about executives in one-tier model" and "shareholders can dismiss management board in two-tier model." 103 Finally, the table includes: (v) a variable on strong employee co-determination ${ }^{104}$; and (vi), as a representative condition from the firm-level data of Table 5 (other conditions were also tested), the data on the mean of the largest shareholders. ${ }^{105}$

100 Carsten Q. Schneider \& Claudius Wagemann, Set-Theoretic Methods FOR the SOCIAL SCIENCES: A GuIDE to Qualitative Comparative ANAlysis 27-30 (2012).

101 Coded as: 1 = traditional two-tier, only recent choice (with recent defined as 2010s); 0.75 = traditional two-tier, medium-term choice (defined as 1995-2009); $0.5=$ long-term choice; 0.25 = traditional one-tier/board of auditors, medium-term choice; $0=$ traditional one-tier/board of auditors, only recent choice. Note for Netherlands: 0.5 for small companies and 1 for large companies $=$ coded as 0.75 overall.

102 Coded as follows: (i) for two tier: $1=$ two persons; $0.33=$ four persons; $0=$ five persons; (ii) for one tier: $1=$ one person; $0.66=$ two persons; $0.33=$ three persons; 0 = four persons; (iii) comparison: 1 if two does not require more than 1.5 more persons than one-tier; 0.5 if it requires twice as many persons; 0 if it requires four times as many persons.

103 Coded as in supra Table 4.

104 Coded as 1 for co-determination unless threshold 100 or higher or ten percent or lower participation rate when it was coded as $0.5 ; 0$ for countries without co-determination.

105 Coded as: 1 for the lowest level of concentration $(<50 \%)$, then $0.5(<66.66 \%)$, then $0.25(<80 \%)$, and 0 for the highest level of concentration $(>80 \%)$. 


\section{b. Correspondence Analysis}

Correspondence analysis is an explorative statistical technique ${ }^{106}$ that aims at generating a graphical mapping of data that was originally developed for two-way contingency tables, but can be used for any data matrix with non-negative entries. ${ }^{107}$ Historically, correspondence analysis has often been used in linguistics, ${ }^{108}$ social sciences ${ }^{109}$ and business studies (e.g., in marketing). ${ }^{110}$ It can also be used to analyze multiple response tables, for example to describe the results of a qualitative survey where the rows represent survey respondents or groups of survey respondents that share a characteristic of interest. The columns thus represent specific words or groups of ideas that came up for respondents. 111 The data are transformed into a low-dimensional vector space, 112 meaning that they can be plotted in a low number of (in simple cases just two) dimensions, which permits a relatively intuitive interpretation.

To our knowledge, correspondence analysis has not yet been used as a tool for comparative law, for which we have adapted the method. We modified the technique to code "country groups" as row profiles (as explained in the next paragraph) and the legal and practical characteristics (as in Table 6, above) as column profiles. Thus, compared to correspondence analysis of a qualitative survey with open-ended questions, we have substituted countries for survey respondents, and replaced survey responses to our coding of

106 This means that correspondence analysis does not test data against a theoretical model or hypothesis, but allows a researcher to see patterns in the data that will hopefully result in a better understanding and possibly the generation of hypotheses. See Michael GREENACRE, CORRESPONDENCE ANALYSIS IN PRACTICE 7 (3rd ed. 2017).

107 See Hervé Abdi \& Michel Béra, Correspondence Analysis, in EnCYClOPEDIA OF Social Network ANALysis AND Mining 1 (R. Alhajj, J. Rokne eds., 2017).

108 On the historical origins in linguistics, see MiCHAEL GREENACRE, THEORY AND APPLICATION OF CORRESPONDENCE ANALYSIS 9-11 (1984).

109 E.g., Julia M. Puaschunder, On the Social Representations of Intergenerational Equity, 4 ACRN OXFORD. J. FIN \& RISK. PERSP. 78 (2015).

110 E.g., Donna L. Hoffman \& George R. Franke, Correspondence Analysis: Graphical Representation of Categorical Data in Marketing Research, 23 J. MKTG. RscH. 213 (1986).

111 For a socio-legal application (possibly the only one in the legal literature), see Bernard E. Harcourt, Measured Interpretation: Introducing the Method of Correspondence Analysis to Legal Studies, U. ILL. L. REV. 979 (2002) (coding a survey about the social meaning of guns among youths).

112 Michael GREENACRE, THEORY AND APPLICATION OF CORRESPONDENCE ANALYSIS 54 (1984). 
legal and practical features of each country's corporate governance system.

Since we are not interested in features of individual countries, but whether the features represented by the column profiles are associated with specific outcomes, we consolidated the countries into groups showing the "dominant model": in four countries the two-tier model dominates with a percentage of more than fifty percent; in four additional countries the one-tier model prevails with more than fifty percent, but there is a sizable number of two-tier firms; finally, in six countries the traditional one-tier or audit model was chosen by more than ninety-nine percent of companies, leaving only a minute number of two-tier firms.113 Thus, for the actual c orrespondence analysis this information was adapted by taking averages within each group. 114

To map the data graphically, the correspondence analysis algorithm computes how each row and each column influences the distribution of the result in two dimensions. In our case (see Figure 5 , below), Dimension 1 explains $72.05 \%$ of the variation, while Dimension 2 explains the remaining $27.95 \%$. Generally speaking, row profiles (and correspondingly, column profiles) that are close to each other have similar effects. ${ }^{115}$ Column and row profiles can be interpreted in relation to each other when a so-called asymmetric plot is used in which one type of profile is normalized to the same scale as the respective other types of profile.116 We use a modified type of asymmetric profile, specifically a column-based contribution biplot as recommended by Greenacre. ${ }^{117}$ With this method, coordinates are weighted according to the inertia of each observation. Thus, row variables that influence the distribution because of their high variation more strongly appear farther away from the origin.

113 Specifically, the coding is therefore: "2Tier $>50 \%$ " for Croatia, Czech Republic, Romania and Slovenia; "1Tier/audit $>50 \%$ " for Finland, Hungary, Lithuania and Netherlands; "1Tier/audit $>99 \%$ " for Bulgaria, Denmark, France, Italy, Luxembourg, and Portugal.

114 For example, the average for entrenched two-tier among countries within the "2Tier $>50 \%$ " category is $(1+1+0.25+.75) / 4=0.75$.

115 See Abdi \& Béra, supra note 107, at 5.

116 See Abdi \& Béra, supra note 107, at 6.

117 See Michael Greenacre, Contribution Biplots, 22 J. Computational \& GRAPHICAL STAT. 107 (2013). 
While the results of correspondence analysis can be presented numerically, 118 they can be more intuitively interpreted in a graphical map. Figure 5 can be interpreted as follows: rows (country groupings) indicated with black triangles are associated with columns (legal and practical factors within the countries) shown with gray circles that lie on a similar direction from the origins. ${ }^{119}$ In other words, the smaller the angle between a line from the origin to the point representing the country group and the line from the origin to the point representing factor of interest, the more associated the factor is with the country group. For example, countries where more than fifty percent of firms follow the two-tier model are relatively likely to have an entrenched two-tier system. If a row profile and a column profile are on opposite side of the plot, the association tends to be negative. Note that these associations do not represent statistical significance, and that the associations shown are only relative to the other country groupings and points. Points representing column profiles lying further away from the origin are more important for differentiating the rows from each other than points close to the origin.

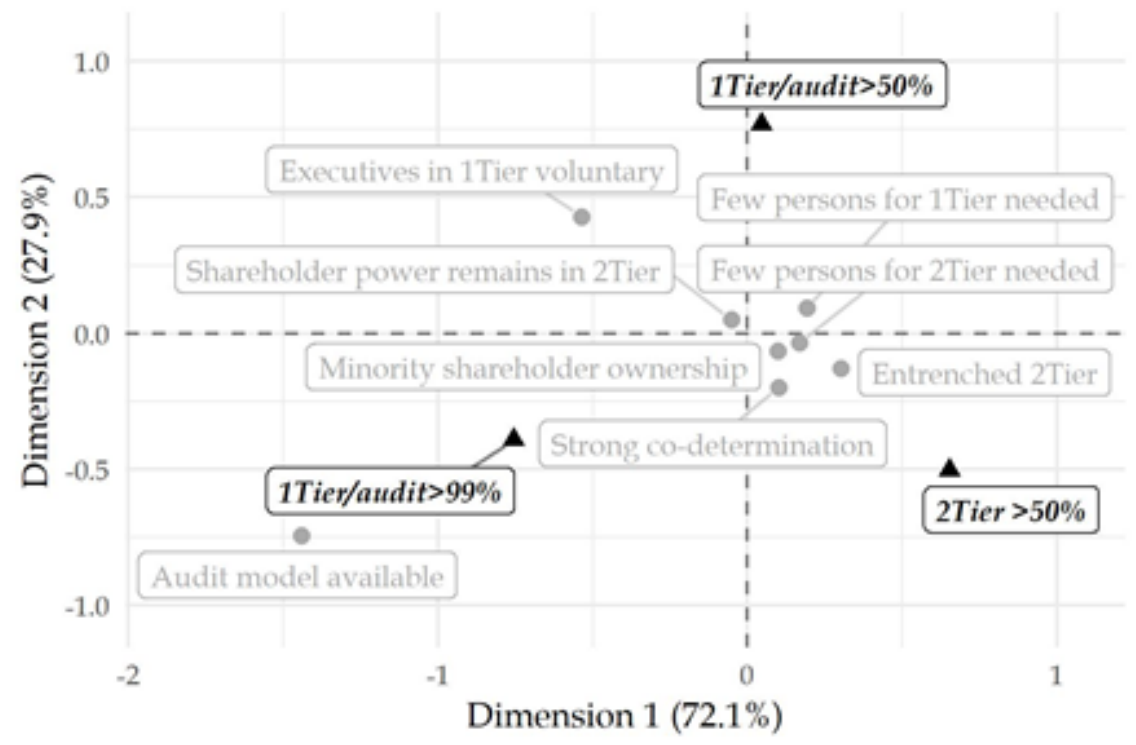

Figure 5: Column-based contribution biplot of correspondence analysis

118 Available from the authors upon request.

119 See Greenacre, supra note 112, at 6. 
Figure 5 shows the results of the two dimensions graphically. The first dimension (along the $x$-axis) separates principally countries where the majority of public companies use the two-tier model and countries where the one-tier or board-of-auditors model prevails overwhelmingly. The second, less important dimension (along the $y$-axis) distinguishes countries where the one-tier model dominates less strongly.

While correspondence analysis only interprets a contingency table graphically and does not tell us whether a relationship is statistically significant, it is possible to perform certain checks to determine how stable the results are, and whether they are driven by idiosyncratic factors in specific countries. One such technique is the so-called "jackknife," where each observation is removed in turn to see whether the results change. We therefore re-ran the analysis fourteen times with a different country removed each time to see whether single countries strongly influenced the placement of row profiles. Another technique is the "bootstrap", where the analysis in question is re-run by repeatedly taking samples from the data (with replacement). We performed the bootstrap by taking 1000 samples out of the fourteen countries (with replacement) and checked how the points for each column profile were typically placed. If a point frequently does not stay close to its location in our main analysis, the original result is less credible. ${ }^{120}$

In our main analysis shown in Figure 5, "Entrenched 2Tier," "Strong co-determination" and "Few persons needed for 2Tier" are most associated with the prevalence of the row profile indicating widespread use of the two-tier model. This is not surprising because these variables indicate a strong tradition of the two-tier model as well as the reduction of two possibly disadvantages, namely the possibility to restrict employee representatives to a supervisory board, and a relatively low cost of the board structure. The bootstrap suggests that the results are most stable for "Entrenched 2Tier." In our main model, this is also the column profile with the third highest inertia (0.017), which is indicated by the distance to the origin in the contribution biplot. The inertias of the other variables

120 On the use of jackknifing and bootstrapping for correspondence analysis, see Greenacre, supra note 112, at 210-19. Some of the more recent literature has suggested creating confidence ellipses based on bootstraps. See ERIC J. BEH \& Rosaria LOMbardo, CORRESPONDENCE ANAlysis: THeOry, PRACTICE AND NeW STRATEGIES 315-17 (2014). We did not use these techniques on the column variables because our main interest was to check whether our results were driven by the choice of countries. 
that show up close to the origin are still weaker $(<0.01)$. The "strong codetermination" variable appears to be in the same direction of the "2Tier $>50 \%$ " row profile mainly because of the inclusion of Slovenia. As shown by jackknifing, when Slovenia is omitted, the profile "strong co-determination" appears to the left of the origin.

The "Audit model available" column profile, which has the highest inertia in the model (0.087), is strongly associated with "1Tier/audit $>99 \%$ " because both countries that have this variable (Italy and Portugal) fall into the latter category. The results are very stable to our robustness tests.

"Executives in 1Tier voluntary," the variable with the second highest inertia (0.058), seems to be associated with both row profiles indicating a majority use of the 1Tier or audit model. In most bootstrap samples, the column profile appears relatively far out in the bottom left quadrant, although in $4.3 \%$ of bootstraps it appears in the bottom right quadrant, and in $9.3 \%$ in the (lower portion) of the top right quadrant. With the jackknife (where countries are omitted in turn), it consistently remains in the top left quadrant. In combination, this seems to suggest that this variable tends to be associated with the use of the one-tier or audit model. By contrast, other variables seem to yield less consistent results, and they have little influence on the variability in the model.

In summary, correspondence analysis supports an interpretation of board choices in the fourteen countries largely been driven by tradition: while all variables associated with a high prevalence of the two-tier model are rather weak, "Entrenched 2Tier" seems to matter most for its prevalence in our fourteen jurisdictions. The availability of the audit model pulls countries most strongly into the opposite direction, i.e., the overwhelming use of either the one-tier or "board of auditors" model. In combination, these results indicate the importance of path dependence for board choice: countries are most likely to use the two-tier or the audit model because it has traditionally been available.

"Executives voluntary in 1Tier" is the most important substantive legal variable (given the second highest inertia). Its location across the origin from "2Tier $>50 \%$ " and between "1Tier/audit $>50 \%$ " and "1Tier/audit $>99 \%$ " could be read as that it pulls countries into the direction of the one-tier model. Arguably, if a country requires firms to appoint executives separately from the board, the latter model often approximates the two-tier model in practice. Thus, it would erode a key difference between the one-tier and two-tier models. By contrast, if the appointment of executive 
can be avoided, especially small firms are not subject to a potentially costly bureaucratic requirement.

\section{c. Fuzzy-set Qualitative Comparative Analysis}

Fuzzy-set qualitative comparative analysis (fsQCA) is a technique that formalizes the logic of Boolean algebra. It has become a popular method across many academic disciplines, notably in political science ${ }^{121}$ and management studies (including corporate governance research), ${ }^{122}$ while examples from legal scholarship are still rare. ${ }^{123}$

FsQCA differs from inferential statistics such as regression analysis as it does not require a large number of observations and a small number of explanatory variables, i.e., it can work with a small number of observations and a relatively large number of explanatory factors (in the fsQCA terminology: "conditions"). More specifically, it aims to "facilitate a dialogue between theory

121 See, e.g., Eva Thomann, Customizing Europe: Transposition as Bottom-Up Implementation, 22 J. EUR. PUB. POL'Y 1368 (2015) (discussing how European Union (EU) member states adapt EU directives to domestic contexts using fuzzy-set qualitative comparative analysis); Axel Marx, Benoît Rihoux \& Charles Ragin, The Origins, Development, and Application of Qualitative Comparative Analysis: The First 25 Years, 6 EUR. POL. SCI. REV. 115 (2014) (explaining the origins of the ideas behind the qualitative comparative analysis).

122 See, e.g., Ilir Haxhi \& Ruth V. Aguilera, An Institutional Configurational Approach to Cross-National Diversity in Corporate Governance, 54 J. MGMT. STUD. 261 (2017) (explaining corporate governance patterns using fuzzy-set logic); Roberto García-Castro, Ruth V. Aguilera \& Miguel A. Ariño, Bundles of Firm Corporate Governance Practices: A Fuzzy Set Analysis, 21 CORP. GOVERNANCE 390 (2013) (exploring how combinations of corporate governance practice in different national governance systems led to high firm performance using fuzzy-set/qualitative comparative analysis).

123 See, e.g., T.T. Arvind \& Lindsay Stirton, Explaining the Reception of the Code Napoleon in Germany: A Fuzzy-Set Qualitative Comparative Analysis, 30 LEGAL STUD. 1 (2010) (explaining the reception of the Code Napoleon in Germany using fuzzy-set qualitative comparative analysis); Pablo José Castillo Ortiz, Councils of the Judiciary and Judges' Perceptions of Respect to Their Independence in Europe, 9 HAGUE J. RULE OF LAW 315 (2017) (discussing the perceptions of European Judges of respect to Judicial Councils in Europe with the aid of multi-value qualitative comparative analysis); Catalina Goanta \& Mathias Siems, What Determines National Convergence of EU Law? Measuring the Implementation of Consumer Sales Law, 39 LEGAL STUD. 714 (2019) (discussing determinants for national convergence of European Union law applies to European consumer sales law using the fuzzy-set Qualitative Comparative Analysis method). 
and evidence"124; thus, it also asks researchers to use qualitative skills and knowledge in research design and evaluation. The results of fsQCA show how different pathways (i.e., combinations of certain conditions) can lead to the same outcome of interest. It is therefore argued that fsQCA's ability to account for causal complexity is one of its key advantages (i.e., it does not simply assume that the same conditions matter for all observations). ${ }^{125}$ FsQCA thus illustrates actual associations between causal pathways and outcomes that were observed within the sample, but it does not state that these pathways must necessary operate in the same way out-of-sample (i.e., in the present study, in countries outside our study).

FsQCA is an extension of "Qualitative Comparative Analysis" (QCA) which codes conditions in a binary way in order to show the different combinations of conditions that can produce a particular outcome. ${ }^{126}$ The "fuzzy-set" in fsQCA means that intermediate numbers between " 0 " and " 1 " are also possible. For the outcome under investigation here, we chose the proportion of firms in a country that have selected the two-tier model (i.e., the percentages as presented in Figure 2, above). The conditions are the ones of Table 6, above, whereby we use the measure "Few persons comparison" for the persons needed in the one-tier and two-tier models. Specifically, we aim to identify conditions that can explain a high use of the two-tier model; thus, we use the variables "Audit model available" and "Executives in 1Tier voluntary" with the inverted values, i.e., as "Audit model not available" and "Executives in 1Tier not voluntary.

124 Marx et al., supra note 121, at 119.

125 Vilmos F. Misangyi, Thomas Greckhamer, Santi Furnari, Peer C. Fiss, Donal Crilly \& Ruth Aguilera, Embracing Causal Complexity: The Emergence of a NeoConfigurational Perspective, 43 J. MGMT. 255 (2017).

126 See Charles Ragin, FUZZY SET/QUalitative COMPARATIVE ANALYSIS, www.socsci.uci.edu/ cragin/fsQCA/ [https://perma.cc/77Z7-M49A]. 
Table 7: Determinants for high and low preference of two-tier model127

\begin{tabular}{|c|c|c|c|c|c|}
\hline \multicolumn{6}{|c|}{ Pathways } \\
\hline & \multicolumn{4}{|c|}{ high 2Tier } & \multirow{2}{*}{$\frac{\text { low } 2 \text { Tier }}{1}$} \\
\hline & 1 & 2 & 3 & 4 & \\
\hline $\begin{array}{l}\text { Entrenched } 2 \text { Tier } \\
\text { Audit model not available } \\
\text { Minority shareholder ownership } \\
\text { Few persons comparison } \\
\text { Executives in 1Tier not voluntary } \\
\text { Shareholder power remains in 2Tier } \\
\text { Strong co-determination }\end{array}$ & $\bullet$ & $\bullet$ & - & • & $\Theta$ \\
\hline Consistency & 0.47 & 0.36 & 0.19 & 0.32 & 0.70 \\
\hline Raw Coverage & 0.91 & 0.37 & 0.19 & 0.27 & 0.40 \\
\hline Unique Coverage & 0.27 & 0.00 & 0.00 & 0.00 & 0.40 \\
\hline Cases with $>0.5$ membership & 5 & 1 & 2 & 0 & 6 \\
\hline Overall Solution Consistency & 0.34 & & & & 0.70 \\
\hline Overall Solution Coverage & 0.91 & & & & 0.40 \\
\hline
\end{tabular}

The pathways of Table 7 can be compared according to "coverage" and "consistency," i.e., the breadth and accuracy of the solutions. ${ }^{128}$ In an ideal world, an interpretation of fsQCA results would also be able to show precisely how each of the pathways accounts for a plausible configuration of conditions. In the present case, we can provide some explanations of the configurations; however, as a caveat, we note that it is not possible to present perfect narratives that would rationalize all of the conditions and pathways

\footnotetext{
127 Calculated with the main software for fsQCA: see Charles C. Ragin and Sean Davey, Software, COMPASSS, https://compasss.org/software/ [https://perma.cc/AB3L-5P5W]. We have chosen the default consistency threshold of 0.8 and the recommended threshold for the number of observations of 1, $c f$. Charles Ragin, User's Guide to Fuzzy-Set / Qualitative Comparative ANALYSIS 47 (Department of Sociology, University of Arizona ed. 2008). This table presents the "parsimonious solution," as "intermediate" and "complex" solutions produce no clear results (noting that other studies too are selective in the way they report the results, for example, García-Castro et al., supra note 122).

128 For more technical definitions see RAGIN, supra note 127, at 85 ("[C]overage measures how much of the outcome is covered (or explained) by each solution term and by the solution as a whole .... [C]onsistency measures the degree to which solution terms and the solution as a whole are subsets of the outcome").
} 
(nor can we exclude that, for particular cases, idiosyncratic factors may play a role $\left.{ }^{129}\right)$.

Specifically, Table 7 shows that entrenchment of the two-tier model is, on its own, the pathway with the highest consistency and coverage. Thus, path dependence is a likely explanation for the continuing choice of the two-tier model. Partly, this may be due to companies which were established at a time prior to the law reform which introduced board choice, but there are also likely to be further factors at play, such as the role of lawyers and other advisors, the availability of case law, standard articles of association etc., ${ }^{130}$ which make businesses choose the traditional board model.131

In the second pathway, the condition on minority shareholder ownership is also relevant on its own, though with lower consistency and coverage. Relatively low shareholder concentration is likely more prevalent in larger companies, which can indeed be expected to be more inclined towards the two-tier model as it offers a more structured way of corporate governance. ${ }^{132}$ In addition, companies with more shareholders may prefer a structure with a supervisory board as this board can represent the interests of both majority and minority shareholders in supervision without involving minority shareholders in management directly.

Three of the legal variables show in the final two high two-tier pathways, though with fairly low coverage. ${ }^{133}$ Thus, while any relevance here should not be overstated, these two pathways also have a degree of plausibility. It makes sense that small companies with often only one or few shareholders want to reduce costs by both putting only few persons on the board(s) and want to avoid weakening the power of shareholders. The combination of remaining shareholder power with strong co-determination is also plausible, given that larger shareholders may prefer the two-tier

129 For such factors see also infra Part IV.D.

130 Such network effects are frequently noted in the discussion about regulatory competition in corporate law. See, e.g., Brett H. McDonnell, Getting Stuck Between Bottom and Top: State Competition for Corporate Charters in The Presence of Network Effects, 31 HofSTRA L. ReV. 681 (2003).

131 For changes see also infra Part IV.D.

132 Of course, there are also means to structure the one-tier model following rules on independent directors, board committees etc.; yet, these rules mainly apply to listed companies, while $98.5 \%$ of the companies in our dataset are non-listed. See supra Part III.B and Part IV.A.

133 Indeed, if we merge the four legal conditions into one, only the first two pathways remain. 
model in order to remain powerful vis-a-vis both employees and directors.

Finally, fsQCA also provides the option to check for the reverse outcome, i.e., in the present case a low use of the two-tier model. This is shown in the final column of Table 7 , using the same conditions as in the positive case (while expecting negative signs). It can be seen that the outcome for the low use of the two-tier model shows one pathway with only a negative effect for "Executives in 1Tier not voluntary." This matches the finding of correspondence analysis that the variable "Executives in 1Tier voluntary" correlates with a frequent choice of the one-tier or audit model. A point to note is that, in contrast to correspondence analysis, the fsQCA results do not show any effect of the availability of the audit model. This may be seen as a surprise, given that in Italy and Portugal the two-tier model is rarely chosen (see Figure 2, above). Yet, the explanation is that in fsQCA the "Executives in 1Tier voluntary" variable captures the same information given that Italy and Portugal score highly in this variable (as do many other countries with a frequent use of the one-tier/audit model, see Table 6, above).

\section{d. Idiosyncratic Factors}

The previous two sub-sections have identified the general role of path dependency for board structure choice. In addition, this subsection explains that some more idiosyncratic reasons also seem to matter. 
Table 8: Change in popularity of board structures for companies established before and after introduction of board choice ${ }^{134}$

\begin{tabular}{|l|l|c|c|c|}
\hline & & One-tier & Two-tier & $\begin{array}{c}\text { Board of } \\
\text { Auditors }\end{array}$ \\
\hline \multirow{4}{*}{$\begin{array}{l}\text { Traditional } \\
\text { One-tier } \\
\text { Countries }\end{array}$} & Denmark & $0.0 \%$ & $0.0 \%$ & - \\
\cline { 2 - 5 } & Finland & $1.1 \%$ & $-1.1 \%$ & - \\
\cline { 2 - 5 } & Luxembourg & $-0.2 \%$ & $0.2 \%$ & - \\
\cline { 2 - 5 } & Romania & $20.0 \%$ & $-20.0 \%$ & - \\
\hline $\begin{array}{l}\text { Traditional } \\
\text { Audit } \\
\text { Countries }\end{array}$ & Italy & $<0.1 \%$ & $<0.1 \%$ & $-0.1 \%$ \\
\cline { 2 - 5 } & Portugal & $-0.2 \%$ & $0.0 \%$ & $0.2 \%$ \\
\hline \multirow{4}{*}{$\begin{array}{l}\text { Traditional } \\
\text { Two-tier } \\
\text { Countries }\end{array}$} & Croatia & $4.0 \%$ & $-4.0 \%$ & - \\
\cline { 2 - 5 } & Czech Republic & $31.3 \%$ & $-31.3 \%$ & - \\
\cline { 2 - 5 } & Hungary & $29.5 \%$ & $-29.5 \%$ & - \\
\cline { 2 - 5 } & Netherlands & $15.9 \%$ & $-15.9 \%$ & - \\
\cline { 2 - 5 } & Slovenia & $27.6 \%$ & $-27.6 \%$ & - \\
\hline
\end{tabular}

Table 8 is based on data that show how far firms established after the introduction of board choice - for the dates see Figure 1, abovehave more or less frequently adopted the new model than the previously established companies. ${ }^{135}$ It can be seen that in five of the six traditional one-tier/audit countries the percentage change is very small. For Denmark and Finland, it may also matter that influential bodies are skeptical about the new model: in Denmark, the Danish Corporate Governance Committee publicly expressed a preference for the traditional one-tier model as "constructive and value-creating" 136; and in Finland, a report by the Chamber of Commerce expressed skepticism toward the two-tier model, for example, referring to supervisory board members as overpaid and

134 In this table we omit the three countries without recent change, Bulgaria, France, and Lithuania, but include the Netherlands as it facilitated board choice in 2013 (though it was also available for smaller companies previously). See supra Part II.C.

135 Detailed time-series analysis will be the topic of a companion paper.

136 Ringe, supra note 19, at 38 (referring to "Committee on Corporate Governance (2014), Recommendations on Corporate Governance"). 
lacking the expertise and motivation to fulfil their supervisory role. ${ }^{137}$

Romania deserves special attention as Table 8 shows the anomaly that the one-tier model has become even more popular for companies established post-choice. The explanation is that, when choice was introduced, more pre-choice companies switched to the two-tier model than new companies choosing it in subsequent years. The data from Romania also deviate in other respects, notably because it is the one-tier model that is more popular with listed companies than the two-tier one. ${ }^{138}$ Further analysis of the Romanian data reveals that more than one third of its public companies were established in the early 1990s. These companies were former state-owned enterprises which were directly transformed into public companies, initially often with significant state ownership. The majority of these companies are not listed and many of them implemented the two-tier model when it was introduced in Romania in 2006. Romanian corporate law experts have suggested to us that politicians and state officials were keen on obtaining positions on these companies' supervisory boards. Thus, it is these specific companies drive the peculiar result as regards the post-choice preferences for the two-tier model in Romania.

The previous sub-sections found that entrenched practices are the best explanation for why traditional two-tier countries still have a relatively high number of firms using the two-tier model. However, Table 8 also shows that there is a decline of the two-tier model as the new one-tier model has gained considerable attraction in most of them (averaging the percentages of the five countries leads to an increase in one-tier of $21.66 \%$ and a corresponding decrease in two-tier use).

\footnotetext{
137 Leena Linnainmaa, Hallintoneuvosto ei tehosta omistajaohjausta, $\begin{array}{lll}\text { KAUPPAKAMARIN UUTISHUONE (Jan. } & 1, & 2014) \\ \text { https://web.archive.org/web/20140210152846/http://kauppakamari.fi/uutishu }\end{array}$ one/page/2/.

138 See supra Part III.B.
} 


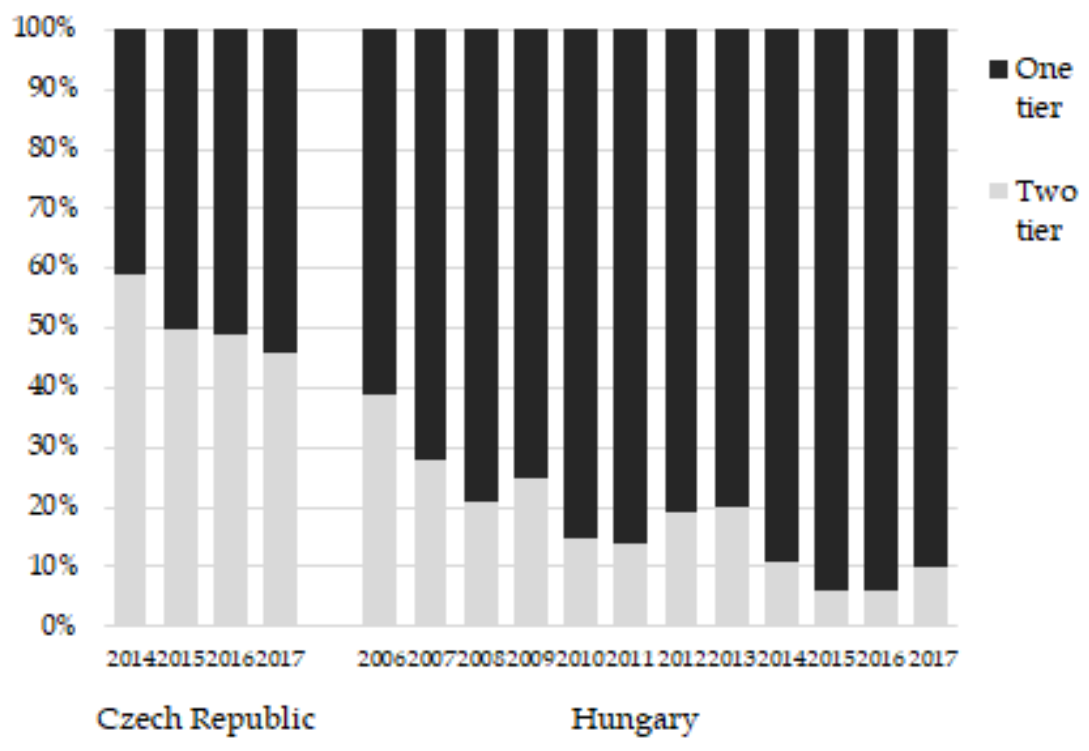

Figure 6: Board models of newly established companies by year of establishment following the introduction of the one-tier model in Czech Republic and Hungary

For the "new" two-tier companies, it is then also revealing to examine whether their data on the time of establishment reflect a continuing time-trend in favor of the one-tier model post-choice; in other words: does the introduction of choice in the five traditional two-tier countries mean that the use of the two-tier model declines further in the post-choice years? Figure 6 shows that in the Czech Republic and Hungary we can indeed observe that post-choice the one-tier model further advances and the two-tier model further declines. In the other three traditional two-tier countries (Croatia, Slovenia, the Netherlands), the time trends of corresponding charts (not displayed here) are inconsistent; yet, in Croatia and Slovenia there are only few newly established public companies per year anyway (sometimes only single-digit figures); and with respect to the Netherlands, the recent reform was only relevant for large public companies (while smaller public companies already had choice prior to the reform). ${ }^{139}$

139 See supra Part II.C. 


\section{CONCLUSION}

Today, many European countries allow the choice between a one-tier model and a two-tier board model, with Italy and Portugal also providing the choice of a third model with a board of auditors. Yet, data on the country differences of these choices are rare. In this article, we aimed to fill this gap, having collected data about the choice of board models in Europe and using both conventional descriptive statistics and innovative techniques in order to make sense of this data at the country level.

Methodologically, this article's use of correspondence analysis and qualitative comparative analysis also had the aim of showing how these techniques developed by other academic disciplines can be fruitfully applied in comparative legal research. One of their main advantages is that they do not depend on a large number of observations as is the case for econometric methods. They are also intuitive to use for legal scholars as both correspondence analysis and qualitative comparative analysis are not simply based on particular numerical scores (such as significant levels) but ask researchers to use their qualitative skills and knowledge in research design and evaluation. While this latter aspect introduces a degree of subjectivity, these methods provide more objectivity than any unbound interpretation of the underlying data.

In substance, our data show that there are profound country differences in the prevalence for one of the board models: in general, the one-tier model is more popular, but there are also some countries with a preference for the two-tier model, while in Italy and Portugal the model with a board of auditors has remained the dominant one. Exploring possible reasons for these different country preferences, we found that path dependence is the main determinant for country differences in the preference for a particular board model. Yet, legal differences also had some impact: here we mainly found that leaving flexibility in the one-tier model about the appointment of executives fosters its use, while there is also some evidence that the use of the two-tier model is more pronounced if a country has low minimum requirements for number of two-tier board members, shareholders retain the power to dismiss management board members in the two-tier model, and it has strong requirements of employee co-determination.

Finally, despite the path dependence of the use of board models, our analysis has shown that introducing board choice has often led 
to a gradual decline of the two-tier model. Should this latter finding be interpreted in a normative way in favor of the one-tier and against the two-tier model? Without further analysis, this would be premature as it is well possible that the remaining two-tier companies benefit from this board structure (e.g., due to a greater need for structured supervision in larger companies). ${ }^{140}$ We do recommend, however, that countries which only allow a two-tier structure should introduce an optional one-tier structure as the foregoing analysis indicates a clear demand for a one-tier structure across all countries.

140 For the normative discussion, see supra Part II.B. 